
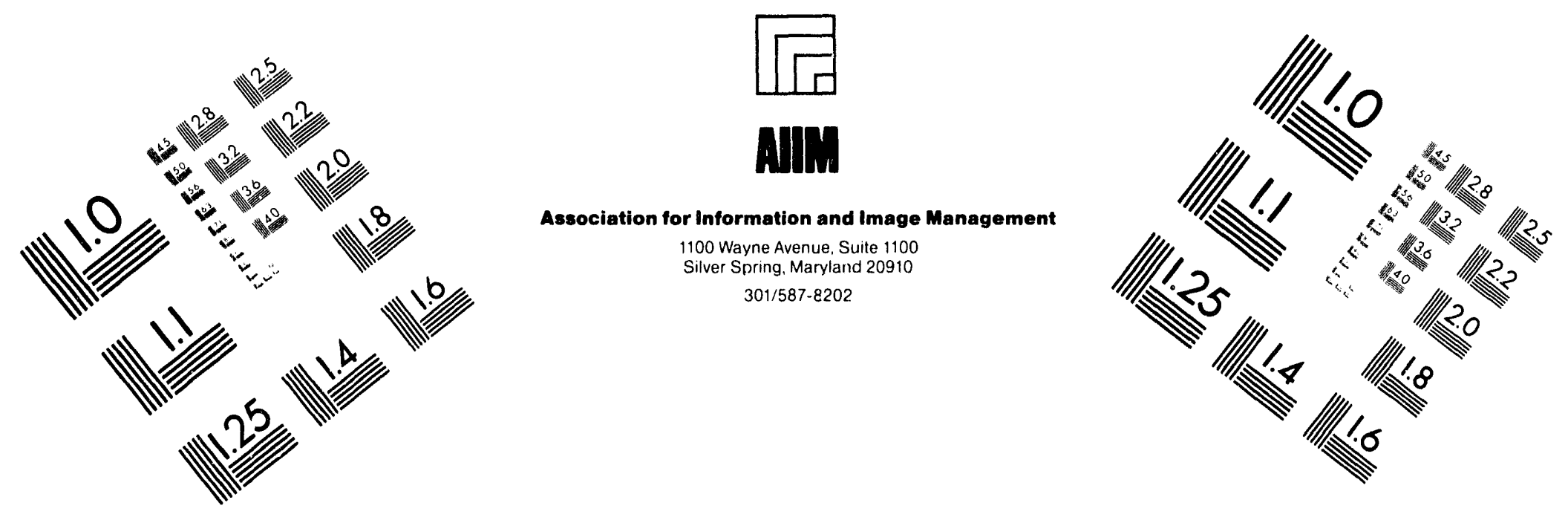

\title{
Centimeter
}

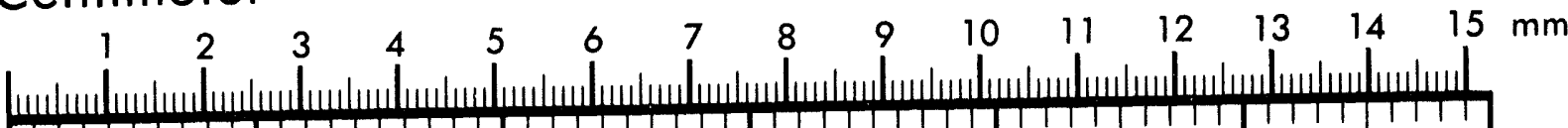

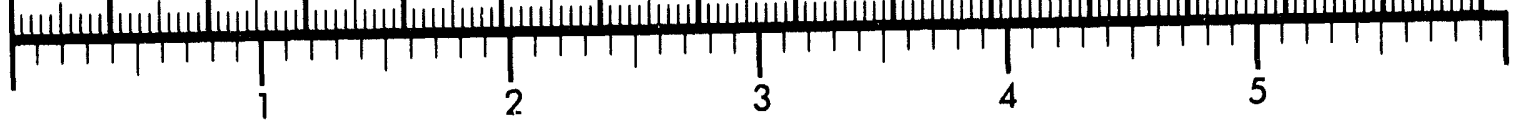
Inches
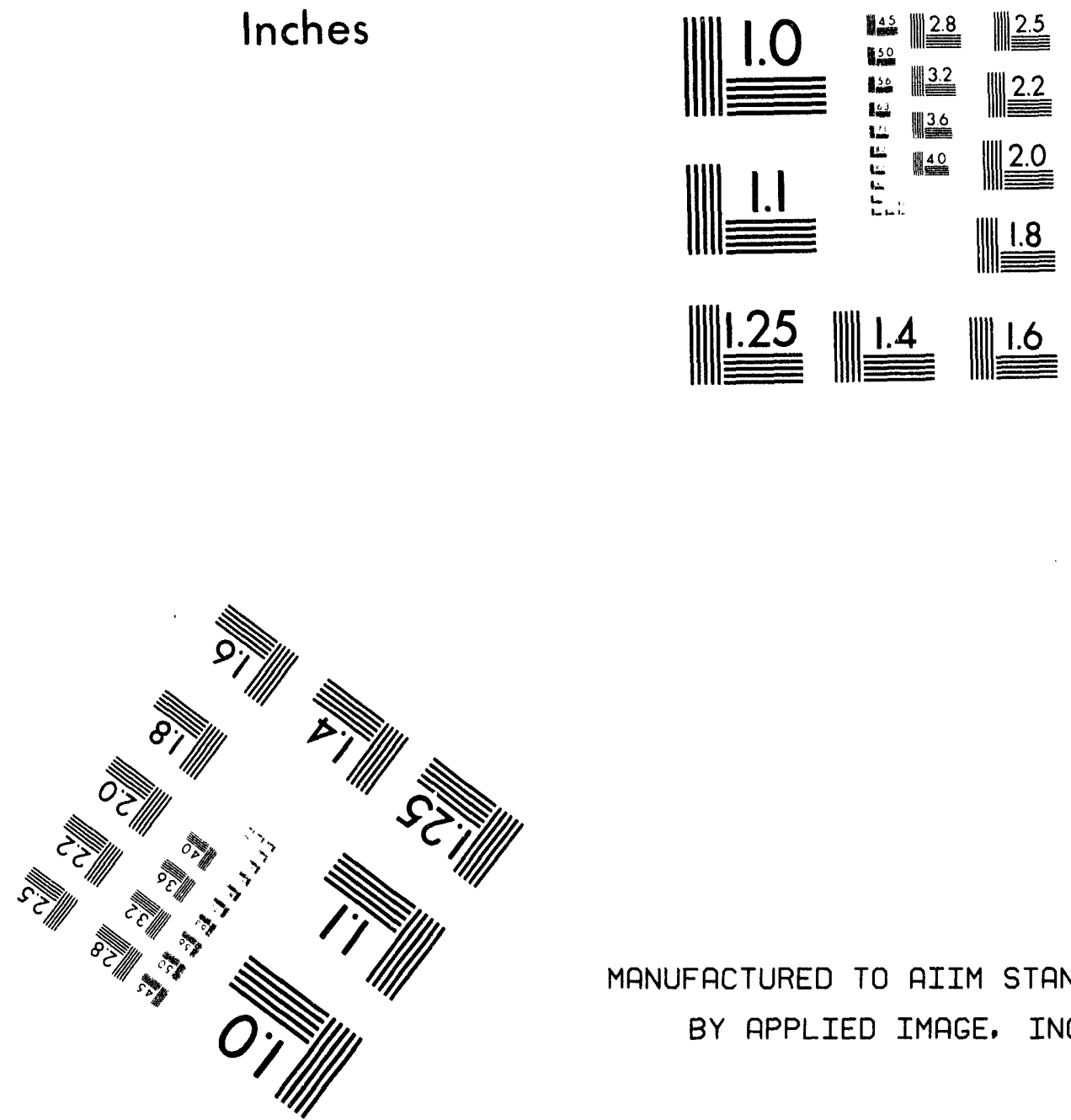

MANUFACTURED TO AIIM STANDARDS

BY APPLIED IMAGE, INC.

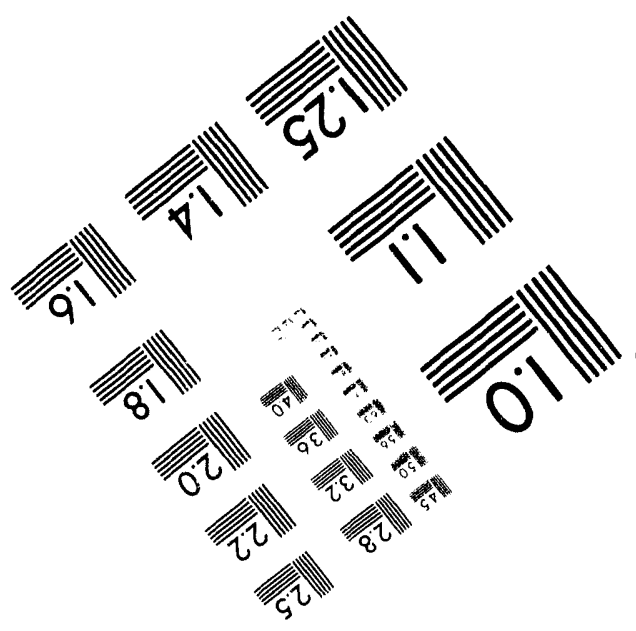



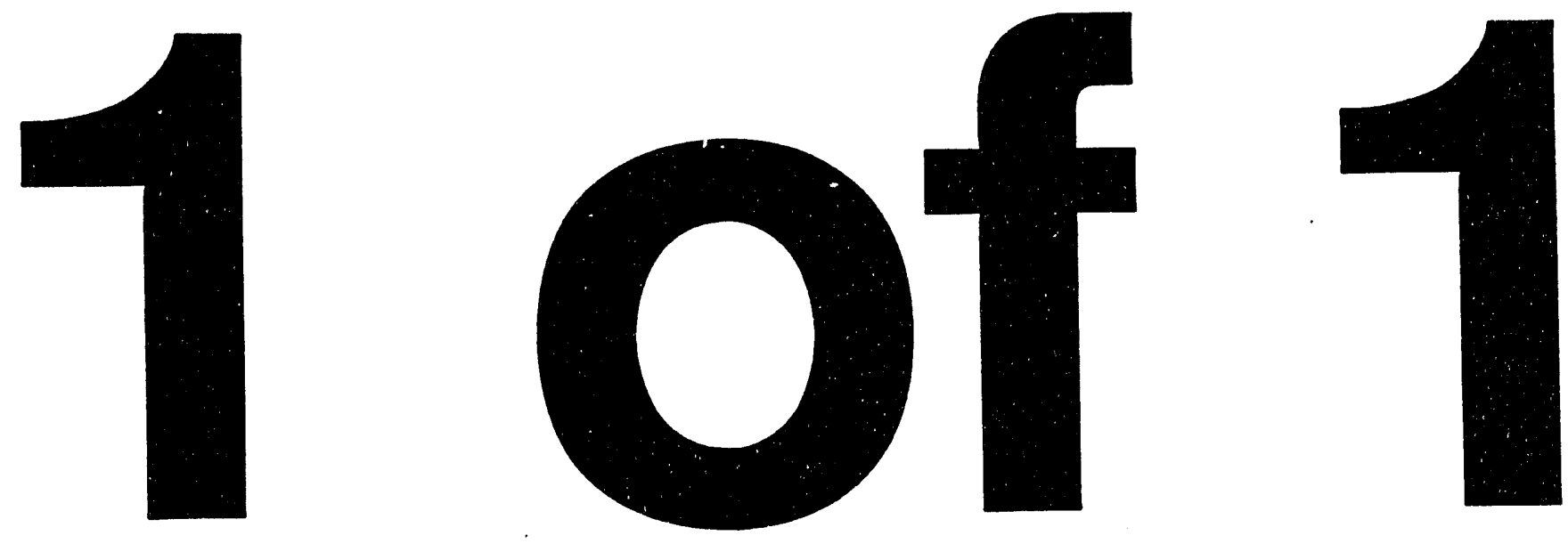


\title{
RECEIVED SEP 1919.34
}

\section{The Sort On Radioactive Waste Type Model: A Method to Sort Single-Shell Tanks Into Characteristic Groups} OSTI

\author{
J. G. Hill \\ B. C. Simpson*
}

August 1994

Prepared for

the U.S. Department of Energy

under Contract DE-AC06-76RLO 1830

Pacific Northwest Laboratory

Richland, Washington 99352

*Westinghouse Hanford Company 
PNL-9814 Rev. 1

\section{EXECUTIVE SUMMARY}

The Sort on Radioactive Waste Type (SORWT) model presents a method to categorize Hanford Site single-shell tanks (SSTs) into groups of tanks expected to exhibit similar chemical and physical characteristics based on their major waste types and processing histories. This model has identified 29 different waste-type groups encompassing 135 of the 149 SSTs and $93 \%$ of the total waste volume in SSTs. The remaining 14 SSTs and associated wastes could not be grouped according to the established criteria and were placed in an ungrouped category. This letter report will detail the assumptions and methodologies used to develop the SORWT model and present the grouping results. Included with this report is a brief description and approximate compositions of the single-shell tank waste types.

In the near future, the validity of the predicted groups will be statistically tested using analysis of variance of characterization data obtained from recent (post-1989) core sampling and analysis activities. In addition, the SORWT model will be used to project the nominal waste characteristics of entire waste type groups that have some recent characterization data available. These subsequent activities will be documented along with these initial results in a comprehensive, formal PNL report cleared for public release by September 1994. 


\section{CONTENTS}

EXECUTIVE SUMMARY $\ldots \ldots \ldots \ldots \ldots \ldots \ldots \ldots$ iii

LIST OF ACRONYMS \& ABBREVIATIONS $\ldots \ldots \ldots \ldots \ldots \ldots$

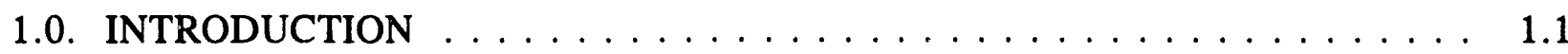

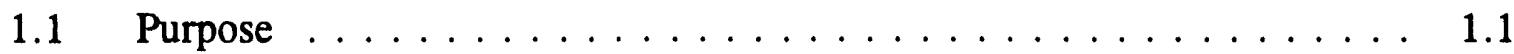

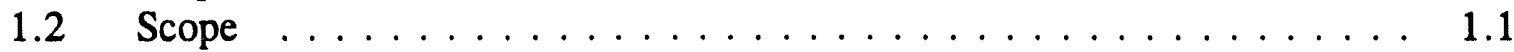

1.3 Background ......................... $1 . \ldots$

2.0 DEVELOPMENT OF THE SORWT MODEL $\ldots \ldots \ldots \ldots \ldots \ldots$

2.1 SORWT Model Background . . . . . . . . . . . . . . . 2.1

2.2 Data Sources for the SORWT Model . . . . . . . . . . . . . 2.1

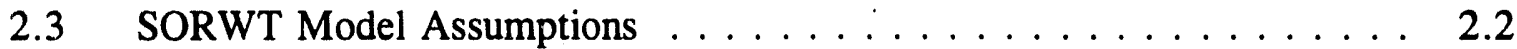

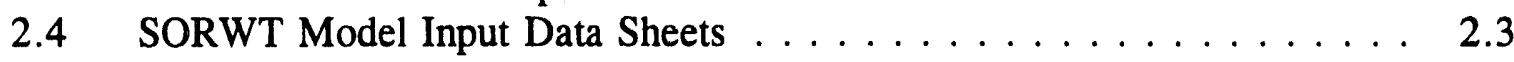

2.5 SORWT Model DBASE File ................. 2.3

3.0 PRESENTATION OF SORWT MODEL RESULTS $\ldots \ldots \ldots \ldots \ldots$

3.1 SORWT Model Report Format . . . . . . . . . . . . . . . . 3.1

3.2 Summary of SORWT Model Waste Type Groups . . . . . . . . . . . 3.1

3.3 Description of SORWT Waste Type Groups . . . . . . . . . . . 3.3

3.3 .1 Group I - R, EB . . . . . . . . . . . . . . . . 3.3

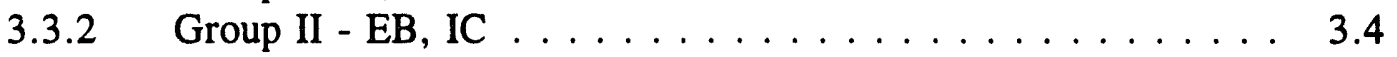

3.3 .3 Group III - TBP-F, EB-ITS $\ldots \ldots \ldots \ldots \ldots . \ldots \ldots$

3.3 .4 Group IV - TBP, CW $\ldots \ldots \ldots \ldots . \ldots \ldots$

$3.3 .5 \quad$ Group $V-224 \ldots \ldots \ldots \ldots \ldots \ldots$

3.3 .6 Group VI $-\mathrm{R} \ldots \ldots \ldots \ldots . \ldots \ldots$

3.3 .7 Group VII $-\mathrm{EB}, \mathrm{R} \ldots \ldots \ldots \ldots . \ldots \ldots$

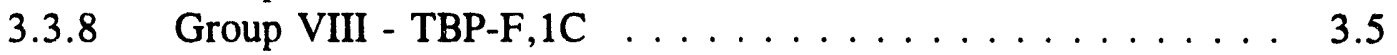

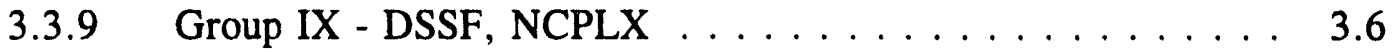

3.3 .10 Group $\mathrm{X}-\mathrm{EB}, \mathrm{CW} \ldots \ldots \ldots \ldots$

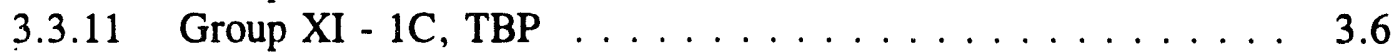

3.3 .12 Group XII -1 C, EB $\ldots \ldots \ldots \ldots . \ldots \ldots$

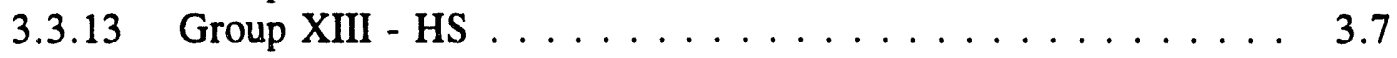

3.3 .14 Group XIV $-2 \mathrm{C}, 224 \ldots \ldots \ldots \ldots \ldots \ldots \ldots$

3.3 .15 Group XV $-2 \mathrm{C}, 5-6 \ldots \ldots \ldots \ldots \ldots \ldots$

3.3 .16 Group XVI $-\mathrm{R}$, RIX $\ldots \ldots \ldots \ldots \ldots \ldots \ldots \ldots$

3.3 .17 Group XVII $-1 \mathrm{C}, \mathrm{CW} \ldots \ldots \ldots \ldots \ldots$

3.3 .18 Group XVIII - CW, EB $\ldots \ldots \ldots \ldots \ldots \ldots$

3.3 .19 Group XIX $-\mathrm{CW}$, MIX $\ldots \ldots \ldots \ldots . \ldots \ldots$

3.3 .20 Group $\mathrm{XX}-\mathrm{CW} \ldots \ldots \ldots \ldots \ldots \ldots$

3.3 .21 Group XXI - TBP, EB-ITS .............. 3.9 
PNL-9814 Rev. 1

3.3.22 Group XXII - EB, TBP $\ldots \ldots \ldots \ldots \ldots \ldots \ldots \ldots$

3.3 .23 Group XXIII - SRS, TBP $\ldots \ldots \ldots \ldots \ldots \ldots \ldots \ldots$

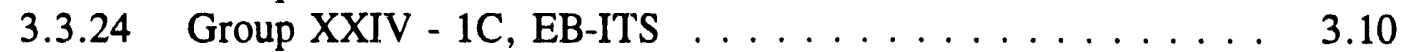

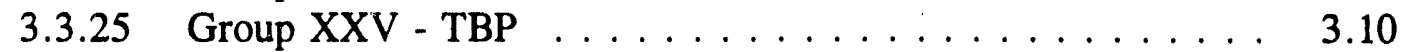

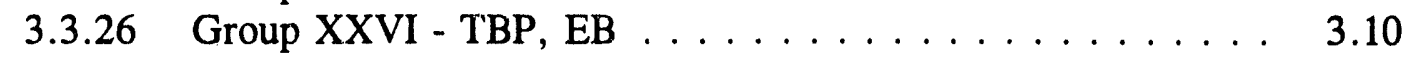

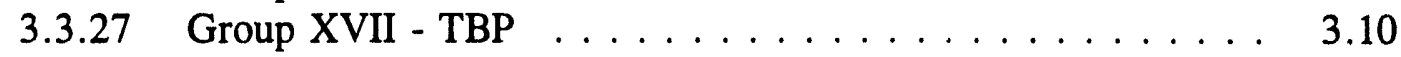

3.3.28 Group XXVIII - CCPLX DSSF $\ldots \ldots \ldots \ldots \ldots \ldots . . \ldots$

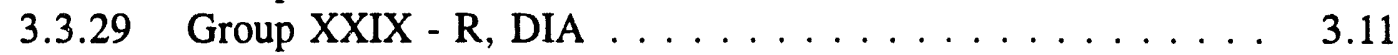

3.3.30 Group XXX - Solitary Tanks (Ungrouped) . . . . . . . . 3.11

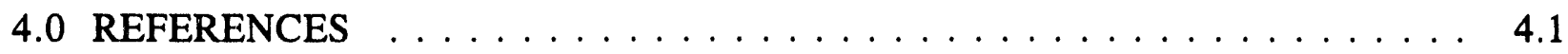

APPENDIX A: Sort on Radioactive Waste Type (SORWT) Model Results . . . . . A A.1

APPENDIX B: Waste Types in Hanford Site Single-Shell Tanks $\ldots \ldots \ldots \ldots$ B.1

\section{TABLES}

1.1 Brief List of Waste Types Abbreviations. . . . . . . . . . . . . . . 1.2

2.1. Sort On Radioactive Waste Type Database File Structure. . . . . . . . . . . . 2.4

3.1. Summary of SORWT Model Results $\ldots \ldots \ldots \ldots \ldots \ldots . \ldots \ldots . \ldots .2$ 


\section{LIST OF ACRONYMS}

$1 \mathrm{C}$

224

$2 \mathrm{C}$

5-6

ANOVA

$\mathrm{BL}$

CC

CY

CCPLX

$\mathrm{CW}$

DIA

DOR

DSSF

DST

DSTATS

DW

EB

$\mathrm{EF}$

$F$

HDRL

HS

ICP

ITS

IX

MIX

MW

NCPLX

OWW

$P$

PUREX

R

REDOX

RESD

RIX

$S$

$S^{2}$

SR-WASH

SORWT

SRS

SST

STD

TBP

TL

TRAC

UK first-cycle decontamination waste

lanthanum fluoride decontamination waste

second-cycle decontamination waste

high-level B Plant waste

analysis of variance

B Plant low-level waste

complexant concentrate

calendar year

complex concentrate

cladding waste

diatomaceous earth

Daily Operating Records

double-shell slurry feed

double-shell tank

descriptive statistics

decontamination waste

evaporator bottoms

evaporator feed

ferrocyanide-scavenged waste

Hanford defense residual liquor

hot semiworks waste

inductively coupled plasma

in-tank solidification

ion exchange waste

mixture of several miscellaneous wastes

metal waste

noncomplexed waste

organic wash waste

neutralized acid waste

plutonium-uranium extraction

high-level REDOX waste

reduction oxidation

residual liquor

REDOX ion exchange waste

sum of the squares

mean sum of the squares

particulates from Sr wash of PUREX wastes in the AR-vault

Sort On Radioactive Waste Type

strontium sludge

single-shell tank

standard deviation

tributyl phosphate

terminal liquor

Track Radioactive Components

Unknown 


\subsection{INTRODUCTION}

\subsection{Purpose}

This report presents a logical method of qualitatively grouping the 149 Hanford Site single-shell tanks (SSTs). The results of this grouping model will enhance the understanding of the contents of the tanks, project the nominal physical and chemical characteristics of an entire group of tanks based upon limited sampling and analysis, and to provide a basis to assess the leak potential of a group of tanks. This model may also provide a basis for sampling optimization.

\subsection{Scope}

The scope of this document is limited to the development of an SST qualitative grouping methodology according to the significant waste types, processing history, and best engineering judgement based on the available information. This letter report does not quantitatively validate the presented model. In the near future, the validity of the predicted groups will be statistically tested using analysis of variance of characterization data obtained from recent (post-1989) core sampling and analysis activities. In addition, the SORWT model will be used to project the nominal waste characteristics of entire waste type groups that have some recent characterization data available. These subsequent activities will be documented along with these initial results in a comprehensive, formal PNL report cleared for public release by September 1994.

\subsection{Background}

Between 1943 and 1964, 149 SSTs were built for the storage of liquid and solid radioactive wastes at the Hanford Site. These SSTs are located in 12 tank farms of 4 to 18 tanks each in the 200 East and 200 West Areas of the Hanford Site. These tanks have been removed from active service and have not received any additional wastes since November 1980. Before the tanks were removed from active service, various waste volume reduction programs were undertaken to minimize the amount of occupied tank volume. These programs involved inter-tank transfers, evaporation, and chemical alterations of the waste. These actions, combined with the ongoing chemical and radiolytic in-tank processes have changed the character of the waste in the SSTs over time, and now the actual composition of the wästes in the SST is not known well enough to make disposal decisions.

However, the wastes in the SSTs originated from a limited number of chemical processes and waste solidification schemes. Tanks which received similar wastes and underwent similar process histories should have a high degree of similarity in chemical content and physical characteristics. This thesis forms the basis of the grouping scheme. A limited number of tanks can provide sufficient information on which to base final processing and disposal decisions, if the tanks selected provide a representative sample of the waste types and conditions in the SSTs. The primary chemical processes at Hanford were the 
$\mathrm{BiPO}_{4}$ plutonium recovery and purification process, the uranium recovery (TBP) process, the REDOX (reduction/oxidation with solvent extraction) process, and the PUREX (plutoniumuranium extraction) process. Each of these major processes also had several affiliated operations, such as the first and second cycle decontamination processes, the lanthanum fluoride process, fuel element decladding, ferrocyanide scavenging, fission product recovery, and several minor associated process wastes (Table 1.1). The waste solidification schemes

Table 1.1. A Brief List of Waste Type Abbreviations

\begin{tabular}{|l|l|}
\hline Waste Acronym & \multicolumn{1}{|c|}{ Meaning of Acronym } \\
\hline R & High-level REDOX waste \\
\hline EB & Evaporator bottoms \\
\hline TBP & Tributyl phosphate waste \\
\hline CC & First-cycle decontamination waste \\
\hline 2C & Second-cycle decontamination waste \\
\hline 224 & Lanthanum fluoride decontamination waste \\
\hline CW & Cladding waste \\
\hline HS & Hot semiworks waste \\
\hline SRS & Strontium leached sludge \\
\hline $5-6$ & High-level B-Plant waste \\
\hline ITS & In-tank solidification \\
\hline RIX & REDOX ion exchange waste \\
\hline DIA & Diatomateous earth \\
\hline DSSF & Double-shell slurry feed \\
\hline CCPLX & Complex concentrate \\
\hline F & Ferrocyanide-scavenged waste \\
\hline NCPLX & Noncomplexed waste \\
\hline SR-WASH & $\begin{array}{l}\text { Paiticulates *from Sr wash of PUREX wastes in } \\
\text { the AR-vault }\end{array}$ \\
\hline MIX & Mixture of several miscellaneous wastes \\
\hline IX & Ion Exchange Waste \\
\hline UK & Unknown Waste Type \\
\hline OWW & Organic Wash Waste \\
\hline
\end{tabular}


generally involved processes that treated waste outside of the tanks, such as the 242-B and 242-T Concentrators and the 242-A and 242-S Evaporator/Crystallizers. These units took the dilute waste from the tank, evaporated the excess water in the waste, and returned the concentrated waste to the tank. However, the in-tank solidification processes removed the excess water directly from a tank using a hot-air sparge (ITS-1) or series of tanks using an in-tank electric heater (ITS-2).

There have been several previous attempts to group the tanks; however, there is no currently accepted method for tank grouping. These previous methods were unacceptable because of their reliance on the TRAC model as a basis (Jungfleisch 1984). The TRAC model can be shown to be internally inconsistent and inconsistent with other sources of reliable information regarding waste in the tanks (Adams et al. 1986; Morgan et al. 1988). The proposed method does not use the TRAC document's quantitative estimates regarding waste composition in the tanks for grouping. The grouping method is instead a qualitative judgement about the tanks that are similar in content and character based on the information in $A$ History of the 200 Area Tank Farms (Anderson 1990) and several generic assumptions about the physical and chemical makeup of the wastes in the tanks. This grouping method then uses a database to sort the tanks on the basis of similarity in overall waste types and processing history.

The groups' similarity will then be tested statistically against quantitative information on a limited number of tank pairs. An analysis of variance (ANOVA) model will be used to compare the core composite results from four pairs of tanks from four different SORWT groups. Thus, this grouping methodology incorporates new information as it becomes available, so any necessary modifications or refinements to the tank grouping method can be made. 


\subsection{DEVELOPMENT OF THE SORWT MODEL}

\subsection{SORWT Model Background}

The SORWT (Sort by Radioa ive Waste Type) model has been developed to categorize tanks into groups expecteu to have similar physical characteristics and chemical compositions. In light of the complex physical and chemical history of the SSTs, especially when several different waste types have been mixed or processed together, the SORWT model does not attempt to predict the composition of a waste tank. Instead, the sorting method concentrates on the different types of waste introduced into each SST, each waste's distinct contribution to the known properties, and the individual significance of each waste type and the process history of each of the tanks. Although the actual chemical reactions and phase equilibria may be unknown when two waste types are combined in a SST, it can be assumed that similar reactions and equilibria occur in other SSTs when the same two waste types are mixed.

The fundamental premise of the SORWT model is that SSTs that received the same waste types in the same approximate proportion and had a similar processing history will be more similar to one another than SSTs that received several different waste types in varying amounts and had a relatively unique process history. In addition, largely supernatant waste types do not have as significant an effect on the character of the waste in the tank as solidforming waste types. Therefore, if the primary and secondary solid-forming waste types can be identified for each SST, the tanks can be grouped based on this criteria. Thus information about the character of the waste in the rest of the members in the group can be deduced from the information obtained by the analysis of the samples from the representative tank, or from a selected number of representative tanks.

\subsection{Data Sources for the SORWT Model}

The principal source of SST waste-type information used by this model has been $A$ History of the 200 Area Tank Farms (Anderson 1990). This document contains much of the available processing history for each of the 149 SSTs from 1944 until 1980. Although this source contains extensive information pertaining to waste types, volumes, and tank transfers, it is not comprehensive and contains many inconsistencies. The historical records used to generate Anderson (1990) were often inaccurate and/or incomplete. The methods utilized to measure accumulated solid and liquid volumes during the early history of the Hanford Site produced inconsistent inventories. Indeed, solids inventories were not routinely taken until the mid-1950s. Often, tank transfer information was missing. Despite these deficiencies, the Anderson document is the best source of SST historical information, and a qualitative assessment of the main solids-forming waste types contained in each SST can be accurately determined.

Often in the course of the process histories of the SSTs, the wastes in the tanks were given new names to reflect their suitability for further processing or the presence of complexing agents. Occasionally, the same waste types were assigned different names at 
different times. For example, terminal liquor (TL), Hanford Defense Residual Liquor (HDRL), and residual liquor (RESD) all identify the same waste. Whenever possible these broad, non-specific waste category names were avoided, and the actual waste type from one of the process operations was used for the sorting criteria. In addition, the suffix $F$ was added to some of the waste types to identify ferrocyanide-scavenged waste, and ITS was added to designate tanks that were in the In-Tank Solidification program.

The volumes of waste contained in each SST were obtained from the Tank Farm Surveillance and Waste Status Summary Report (Hanlon 1990). These values include, on a per tank basis, total waste volume, volume of salt cake, volume of sludge, and volume of supernate. It can be assumed that these values are more accurate than those final values found in Anderson (1990) because they were obtained more recently, however, it is understood that these values have deficiencies also because of the limited access to the tanks.

\subsection{SORWT Model Assumptions}

The underlying assumptions utilized by the SORWT model are as follows:

- The information contained within Anderson (1990) is sufficient to qualitatively identify and rank relative to one another the waste types which contributed to the accumulated solids in each individual SST.

- $\quad$ The SST process history, primary solids-forming, and secondary solids-forming waste types were responsible for the majority of the physical characteristics and chemical compositions of the waste remaining in each SST.

- Supernatant wastes that were not allowed to remain in a tank for a great period of time and later pumped out of the SST had less influence on the physical and chemical character of the waste than did the solid waste types.

- SSTs were often sluiced at some time during their processing history. Sluicing is the process of removing solids from waste tanks using high pressure water jets. Waste types present in the tank prior to the most recent sluicing were not considered relevant by this model.

- Use of a broad-ranging, less descriptive waste type, such as NCPLX, CCPLX, EVAP, and/or DSSF, were avoided whenever possible. The previous nomenclature for those waste types was preferred, if available. However, a broad category identifying the tank waste as either noncomplexed, complexed, or ferrocyanide scavenged waste has been included in the SORWT model to aid in evaluating the results of the model. 


\subsection{SORWT Model Input Data Sheets}

SORWT Model input sheets were generated for each tank by thorough evaluation of the processing histories found in Ande-son (1990) and Hanlon (1990). The waste type judged to be the most significant contributor to the solids volume in any specific SST was identified as the Primary Waste Type. This evaluation was made on the basis of waste volume introduced into each tank and the solids accumulation during the regime of that particular waste. The second most significant solids-forming waste type was identified as the Secondary Waste Type. When appropriate, a Tertiary and Other Waste Type was also identified.

Because waste prior to sluicing has been disregarded by the SORWT Model, the date of the most recent sluicing event for each tank has been included on the input sheets. The volume of waste remaining in the tank after sluicing has also been included to aid in the sorting and analysis. The data were obtained from Anderson (1990).

The waste volumes remaining in each SST, segregated into salt cake, sludge, supernate, and total, were collected from Hanlon (1990). Although the waste volume information was not used as a sorting criterion, it can be used as an indication of grouping feasibility. A realistic group, as predicted by the SORWT Model, exhibiting similar physical and chemical characteristics should not include tanks that have widely varying ratios between sludge and salt cake. If the majority of tanks in a group contain all sludge and one tank contains all salt cake, the membership of that tank in the group would be in question. The tank waste volume information provides valuable insight into those tanks in a group that have greater significance due to their higher volume.

\subsection{SORWT Model DBASE File}

A database file was created to store and manipulate the data from the input sheets. The field structure of this database can be seen in Table 2-1.

The information contained on the SORWT data input sheets was entered into the database. The SORWT database file was then indexed on the WASTE1, WASTE2, WASTE3, and WASTE4 fields, respectively. 
Table 2.1. Sort On Radioactive Waste Type Database File Structure

\begin{tabular}{|c|c|c|c|c|}
\hline \multicolumn{5}{|c|}{ Structure for Database: D:SORWT.DBF } \\
\hline \multicolumn{5}{|c|}{ Number of Data Records: 149} \\
\hline \multicolumn{5}{|c|}{ Data of Last Update: $04 / 12 / 91$} \\
\hline Field & Field Name & Type & Width & Dec \\
\hline 1 & TANK_NAME & Character & 6 & \\
\hline 2 & W_CATEGORY & Character & 1 & \\
\hline 3 & WASTE1 & Character & 6 & \\
\hline 4 & WASTE2 & Character & 6 & \\
\hline 5 & WASTE3 & Character & 6 & \\
\hline 6 & WASTE4 & Character & 6 & \\
\hline 7 & DATE_SLUIC & Character & 4 & \\
\hline 8 & VOL_REMAIN & Character & 4 & \\
\hline 9 & SALT_CAKE & Numeric & 4 & \\
\hline 10 & SLUDGE & Numeric & 4 & \\
\hline 11 & SUPERNATE & Numeric & 4 & \\
\hline 12 & TOTAL_VOL & Numeric & 4 & \\
\hline \multicolumn{3}{|c|}{ Total } & 56 & \\
\hline
\end{tabular}




\subsection{PRESENTATION OF SORWT MODEL RESULTS}

\subsection{SORWT Model Report Format}

A report presenting the SORWT model results was generated using a database software package. The report format was structured such that tanks possessing the same primary and secondary waste types were grouped together. The report output from the database package was imported into a word processor for additional editing. The different groups were listed in descending order of importance with the most signiticant group first. The number of tanks within each group has been included with the group heauing. Following each group is a subtotal providing the volume of salt cake, sludge, and total waste represented by that particular waste group as reported in Hanlon 1990. The tank groups were then sub-divided according to their safety watch list status. A full printout of the SORWT model report is presented in Appendix A.

The first column of the SORWT model report contains the group I.D. in Roman numerals. The lower the number, the more significant the group in terms of number of tanks and total waste volume. Column two contains the tank names of the individual tanks that make up each group. The third and fourth columns report the primary and secondary waste types, respectively. These are the waste types that contributed most significantly to the solids volume in that particular tank relative to other waste types introduced into that same tank and are the criteria for tank grouping. Within any given group, the primary and secondary waste types will always be identical. The fifth and sixth columns, respectively, contain the tertiary and other waste types. While the tertiary and other waste types are not actually used as grouping criteria, they are provided for further assistance in interpreting the results. The seventh column presents the safety watch list status of each tank. The codes used in this column are $\mathrm{F}, \mathrm{O}, \mathrm{H}, \mathrm{G}$, and $\mathrm{N}$ representing ferrocyanide, organic, high-heat, gas generating, and non-public law tanks, respectively. The eighth, ninth, and tenth columns contain, respectively, the salt cake volume, sludge volume, and total waste volume for each individual tank.

\subsection{Summary of SORWT Model Waste Type Groups}

The SORWT model has predicted two existence of 29 waste-type groups ranging from a high of 22 tanks per group to a low of two tanks per group. These 29 waste-type groups encompass 135 tanks and $93 \%$ of the total waste volume. A thirtieth group contains the 14 solitary SSTs that did not fall into any waste-type groups. Table 3.1 presents a summary of the SST waste type groups predicted by the SORWT model.

The first column of Table 3.1 identifies the group number. The second column contains the primary and secondary waste types that were used as the grouping criteria. Column three reports the number of tanks in each individual group. The fourth, fifth, and 
PNL-9814 Rev. 1

Table 3.1. Summary of SORWT Model Results

\begin{tabular}{|c|c|c|c|c|c|c|}
\hline $\begin{array}{r}\text { GROUP } \\
\text { NUMBER }\end{array}$ & $\begin{array}{r}P \\
\& S \\
\text { WA }\end{array}$ & $\begin{array}{l}\text { ARY } \\
\text { NDARY } \\
\text { GROUP } \\
\text { PE }\end{array}$ & $\begin{array}{l}\text { NUMBER } \\
\text { OF TANKS } \\
\text { IN GROUP }\end{array}$ & $\begin{array}{c}\% \\
\text { VOLUME } \\
\text { SALT CAKE } \\
\text { ALL TANKS }\end{array}$ & $\begin{array}{c}\% \\
\text { VOLUME } \\
\text { SLUDGE } \\
\text { ALL TANKS }\end{array}$ & $\begin{array}{c}\% \\
\text { TOTAL } \\
\text { VOLUME } \\
\text { ALL TANKS }\end{array}$ \\
\hline I. & $\mathbf{R}$ & EB & 22 & $38 \%$ & $11 \%$ & $28 \%$ \\
\hline II. & EB & 1C & 10 & $20 \%$ & $0 \%$ & $13 \%$ \\
\hline III. & TBP-F & EB-ITS & 10 & $14 \%$ & $5 \%$ & $11 \%$ \\
\hline IV. & TBP & $\mathrm{CW}$ & 9 & $0 \%$ & $5 \%$ & $2 \%$ \\
\hline V. & 224 & & 8 & $0 \%$ & $2 \%$ & $1 \%$ \\
\hline VI. & $\mathbf{R}$ & & 7 & $0 \%$ & $7 \%$ & $2 \%$ \\
\hline VII. & EB & $\mathbf{R}$ & 5 & $8 \%$ & $1 \%$ & $6 \%$ \\
\hline VIII. & TBP-F & $1 \mathrm{C}$ & 5 & $0 \%$ & $4 \%$ & $1 \%$ \\
\hline IX. & DSSF & NCPLX & 4 & $7 \%$ & $3 \%$ & $6 \%$ \\
\hline $\mathrm{X}$. & EB & $\mathrm{CW}$ & 4 & $6 \%$ & $1 \%$ & $5 \%$ \\
\hline XI. & $1 \mathrm{C}$ & TBP & 4 & $0 \%$ & $6 \%$ & $2 \%$ \\
\hline XII. & $1 \mathrm{C}$ & EB & 4 & $0 \%$ & $4 \%$ & $2 \%$ \\
\hline XIII. & HS & & 4 & $0 \%$ & $0 \%$ & $0 \%$ \\
\hline XIV. & $2 C$ & 224 & 3 & $0 \%$ & $7 \%$ & $2 \%$ \\
\hline XV. & $2 C$ & $5-6$ & 3 & $0 \%$ & $4 \%$ & $1 \%$ \\
\hline XVI. & $\mathbf{R}$ & RIX & 3 & $0 \%$ & $3 \%$ & $1 \%$ \\
\hline XVII. & $1 \mathrm{C}$ & $\mathrm{CW}$ & 3 & $0 \%$ & $2 \%$ & $1 \%$ \\
\hline XVIII. & $\mathrm{CW}$ & EB & 3 & $0 \%$ & $2 \%$ & $1 \%$ \\
\hline XIX. & $C W$ & MIX & 3 & $0 \%$ & $1 \%$ & $1 \%$ \\
\hline XX. & CW & & 3 & $0 \%$ & $0 \%$ & $0 \%$ \\
\hline XXI. & TBP & EB-ITS & 2 & $3 \%$ & $1 \%$ & $2 \%$ \\
\hline XXII. & EB & TBP & 2 & $2 \%$ & $0 \%$ & $1 \%$ \\
\hline XXIII. & SRS & SLUICE & 2 & $0 \%$ & $3 \%$ & $1 \%$ \\
\hline XXIV. & 1C & EB-ITS & 2 & $1 \%$ & $2 \%$ & $1 \%$ \\
\hline XXV. & TBP & & 2 & $0 \%$ & $2 \%$ & $1 \%$ \\
\hline XXVI & TBP & EB & 2 & $0 \%$ & $2 \%$ & $1 \%$ \\
\hline XXVII. & TBP & $1 C-F$ & 2 & $0 \%$ & $2 \%$ & $1 \%$ \\
\hline XXVIII. & CCPLX & DSSF & 2 & $0 \%$ & $0 \%$ & $0 \%$ \\
\hline XXIX. & $\mathrm{R}$ & DIA & 2 & $0 \%$ & $1 \%$ & $0 \%$ \\
\hline \multicolumn{3}{|c|}{ TOTAL } & 135 & $100 \%$ & $81 \%$ & $93 \%$ \\
\hline XXX. & \multicolumn{2}{|c|}{ UNGROUPED TANKS } & 14 & $0 \%$ & $19 \%$ & $7 \%$ \\
\hline
\end{tabular}


sixth columns, respectively, contain the percentage by volume of salt cake, sludge, and total waste compared to all 149 SSTs represented by each SORWT waste type group. A total has been accumulated for columns three through nine encompassing the 29 waste type groups predicted by the SORWT model. The ungrouped tanks were not included in this total.

A review of Table 3.1 will quickly reveal that Group I is by far the most significant group. This group includes 22 tanks, $38 \%$ of the total salt cake volume, and over $1 / 4$ of the total waste in all 149 SSTs. The first three groups represent over $1 / 2$ of the total waste volume in all 149 SSTs. This categorization demonstrates the potential usefulness of the SORWT model. Table 3.1 also identifies groups that have relatively no significance, such as Groups XII and XIX, which contain almost no waste. This information can be used in allocating time and resources for characterization activities as well as pretreatment and immobilization development.

There may exist larger families of related tank groups. An example of a potential family is Group I (R, EB) and Group VII (EB, R). These two groups have the same primary and secondary waste types. The relative differences between these two groups due to their respective designation of which of the two waste types is primary and secondary may be small when compared to the overall group variability. Identifying larger families of tanks will reduce the overall number of different groups being evaluated. The existence of families will be tested and reported in the formal report to be issued by the end of the fiscal year.

\subsection{Description of SORWT Waste Type Groups}

To further elaborate on the results of the SORWT Model, brief descriptions of each of the most waste type groups predicted by the model have been developed.

\subsubsection{Group I - R, EB}

As previously mentioned, this waste type group is the most significant group predicted by SORWT in terms of number of tanks and total waste volume. The 22 tanks within this group contain 10,465,000 gallons of total waste--8,884,000 gallons of salt cake and 1,440,000 gallons of sludge. All 22 Group I tanks can be found in three different 200 West Area Tank Farms--S, SX, and TX Farms. These tanks typically received a large amount of high-level REDOX waste (R) during the 1950s. This waste is most likely responsible for the sludge accumulation in these tanks. These tanks also received large amounts of evaporator bottoms (EB), usually from the 242-S Evaporator in the early 1970s. This super-saturated, high-nitrate waste cooled in the SSTs and formed an extremely hard salt cake. Although the processing history of these tanks between the addition of the $R$ in the 1950 s and the EB in the 1970s differs slightly, it is believed that these two waste types predominantly dictate the physical and chemical characteristics of the waste. Some of the tanks in this group have no reported sludge accumulation, probably because poor measurements were taken before salt cake formation. Once the salt cake crystallized in a tank, it became impossible to measure the volume of sludge. Because of the extreme hardness of the salt cake, there are technical obstacles that prevent core sampling any of these tanks at this time. 


\subsubsection{Group II - EB, 1C}

This 10-tank group contains approximately 4,634,000 gallons of waste. The vast majority of this waste- $-4,594,000$ gallons--is salt cake. All but two of these tanks are located in the TX Tank Farm; one is located in B Tank Farm. These tanks are characterized as having received large quantities of EB, mainly from the 242-T Evaporator. They also received modest quantities of $1 \mathrm{C}$ waste. Tank B-105 received $1 \mathrm{C}$ before the $\mathrm{EB}$, which might explain the limited sludge accumulation in this tank that is not exhibited by the others. Once again, the hard salt cake formation raises significant technical issues that must be solved before sampling these tanks.

\subsubsection{Group III - TBP-F, EB-ITS}

This group contains 10 tanks and is the second most significant in terms of number of tanks and total waste volume. The tanks in this group hold 3,980,00 gallons of waste. The majority of this waste--3,344,000 gallons--is presumed to be salt cake. However, these tanks also contain substantial amounts of sludge. All 10 of these tanks, which originally held metal waste (MW) from the bismuth phosphate process, can be found in the BY Farm located in the 200 East Area. They were completely sluiced out in the early 1950s, and no significant amounts of MW remain in the tanks, so they are not considered by the SORWT model. After sluicing, these tanks received tributyl phosphate (TBP) ferrocyanide-scavenged waste from U Plant, which is probably responsible for the sludge buildup. During the late 1960s and early 1970s, these tanks were connected to the in-tank solidification (ITS-2) loops. This process, in which one tank in the loop was used as an in-tank evaporator and the rest of the tanks as liquid holders, concentrated the waste and reduced the liquid volume, resulting in salt cake formation. Because of high concentrations of ferrocyanide in these tanks and the hardness of the salt cake, there are significant safety and technical difficulties associated with sampling this waste type group.

\subsubsection{Group IV - TBP, CW}

This nine-tank group, located almost entirely in BX Tank Farm, contains 687,000 gallons of waste. Nearly all of the contents of this group is sludge. Salt cake has only been observed in one tank (BX-105), and the 3,000 gallons of salt cake is due to a small transfer of EB into that particular tank. These tanks were originally filled with MW in the 1940s. In the early 1950s they were sluiced of their contents to provide room for TBP waste. Additions of this waste type began in the mid-1950s. The addition of cladding waste began in the mid-1960s. The various other transfers that occurred in these tanks should not affect the characteristic of the waste significantly relative to the primary and secondary wastes. Tanks BX-105 and Tank BX-106 were core sampled previously and provide insight into their chemical composition. Additional sampling of these tanks poses no technical or safety issues. 


\subsubsection{Group V - 224}

This eight tank group represents 280,000 gallons of waste. The majority of the waste is sludge; no salt cake formation has been sbserved in these tanks. All eight tanks are 55,000-gallon, 200 Series tanks located in B and T Tank Farms. These tanks received 224 waste exclusively. In light of the singularity of the waste type introduced into these tanks and the similarity of process history (i.e., the near absence of any intertank transfers), the composition among tanks of this group should be very uniform. There are no safety or technical issues prohibiting sampling of these tanks.

\subsubsection{Group VI - R}

Group $\mathrm{V}$ is a seven-tank group containing high-level $\mathrm{R}$ exclusively. These tanks hold 892,000 gallons of waste. Th: majority of waste--888,000 gallons--is sludge, no salt cake formation has been observed. Five of these tanks can be found in the SX Tank Farm, and all are located in the 200 West Area. There are no safety or technical sampling issues associated with the majority of this group; the exception is Tank SX-109, which is on the watch list as a gas-generating tank. Sampling and analysis of S-104 has been performed; assessment of the data is currently pending and will contribute greatly to the existing body of characterization knowledge. The analysis of this tank significantly aids in characterizing this particular seven-tank group and also several other groups containing large amounts of R-type waste. It is of interest to note that $R$ forms sludge without any further waste volume reduction processes.

\subsubsection{Group VII - EB, R}

Group VII consists of five 200 West Area tanks, mostly from U Farm. These tanks contain 2,037,000 gallons of waste, the vast majority of which is salt cake. The tanks were filled with MW in the 1940s, but were completely sluiced out in the early 1950s. Large quantities of high-level $\mathbf{R}$ were introduced into these tanks and allowed to remain there for many years. In the early 1970s, large volumes of $R$ supernate were transferred from the tanks and replaced with EB from the 242-S Evaporator, which caused a salt cake to form in the majority of the tanks. The small amount of sludge that accumulated in these tanks is probably due to the R present before the EB. Because of the hardness of the salt cake, these tanks offer technical difficulties that must be solved before sampling. These tanks should be very similar to Group I tanks and differ from them mainly in the ratios of $R$ to EB. These tanks might be so similar that they can be included with that group; however, these similarities can only be verified by core samples.

\subsubsection{Group VIII - TBP-F, 1C}

This five-tank group contains 478,000 gallons of waste, and approximately 465,000 gallons of that is sludge. No salt cake has been observed in these tanks. The four C Farm tanks were used as the primary settling tanks during the In-Farm Scavenging campaign during the 1950 s, and they were originally filled with $1 \mathrm{C}$ waste in the $1940 \mathrm{~s}$. The supernate was transferred out of the tanks to make room for the TBP-scavenged waste that was allowed to settle. These two wastes formed the vast majority of the solids located in 
these two tanks. The other tank in this group (T-107) has a processing history similar to that of the rest of this group, except that it received its ferrocyanide-scavenged TBP waste from the U Plant scavenge test. These two TBP-F wastes may be slightly different. All of these tanks are on the watch list because of their ferrocyanide content.

\subsubsection{Group IX - DSSF, NCPLX}

This four-tank group contains a total of $2,113,000$ gallons of waste. Salt cake comprises $1,717,000$ gallons of this waste, while 387,000 gallons are sludge. These tanks initially received either plutonium-uranium extraction (PUREX) high-activity, neutralized acid waste (P) or B Plant high-level waste (B). However, all of these tanks were sluiced of their contents in 1976. The waste types added to these tanks after sluicing were DSSF and noncomplexed waste, which are generic terms describing the potential for further processing of the waste instead of the original source of the waste. Because these terms are so general, little can be determined about the homogeneity of the waste in this group. In fact, one tank in this group contains only sludge, while the rest contain mostly salt cake. Although the total volume of this group is highly significant, the uncertainty of the waste types in these tanks makes this group less important.

\subsubsection{Group X - EB, CW}

These four tanks (all in U Farin) contain 1,755,000 gallons of waste. Salt cake comprises $1,520,000$ gallons of this waste, while sludge comprises only 124,000 gallons. These tanks were filled with MW in the late 1940s or early 1950 s; in the mid- to late 1950 s, the $\mathrm{MW}$ was sluiced from the tank to provide room for CW. The supernatant portions of the CW were flushed out of the tanks in the early 1970s by various liquid transfers. In the midto late 1970s, large amounts of EB from the REDOX evaporator and the 242-S Evaporator were added to these tanks. (The EB are responsible for the salt cake formation.) All of the tanks are on the watch list for either gas generation or acetate contents; therefore, there are safety and technical issues pertaining to sampling this tank.

\subsubsection{Group XI - 1C, TBP}

This five-tank group contains 715,000 gallons of waste, the vast majority of which is sludge. Even though this group transcends four different tank farms in both the 200 East and West Areas, these tanks have very similar processing histories. They were filled with $1 \mathrm{C}$ waste in the 1940s. A portion of this volume was drained in the early 1950s, and the tanks began receiving TBP waste. The solids volume that was measured at this time did not accumulate further during the rest of these tanks' histories. The additional transfers were mostly liquid in nature and had little effect on the sludge volume. No salt cake has been observed in these tanks, even though a small amount of EB was introduced into T-108 (apparently not enough to catalyze crystallization). 


\subsubsection{Group XII - 1C, EB}

This four-tank group of B and BX Farm tanks contains 553,000 gallons of waste, nearly all of which is sludge. These tanks all received 1C waste in the late 1940s and early 1950s. In the mid-1950s the supernatant portion of the $1 \mathrm{C}$ waste was transferred from the tanks and they began receiving EB waste. The EB must not have been very concentrated, because the characteristic salt cake did not form. All of these tanks also received appreciable amounts of CW in the 1960s.

\subsubsection{Group XIII - HS}

This four-tank group of 55,000-gallons, 200-Series tanks is located in the C Tank Farm. These tanks received MW in the 1940s but were sluiced in the early 1950s. After sluicing, these tanks received waste only from the Hot Semiworks. The majority of this waste was removed irom these tanks in the late 1960s and early 1970s; the total waste remaining is only 11,000 gallons. This minor volume designates this tank group as being insignificant compared with other groups or even single tanks.

\subsubsection{Group XIV - 2C, 224}

This three-tank group contains 904,000 gallons of total waste. The majority of which, 892,000 gallons, is sludge. These SSTs were connected in a three-tank cascade. The processing history of these tanks is very similar. They all received $2 \mathrm{C}$ waste in the 1940s and early 1950s until the cascade was full. In 1952, they began receiving 224 waste, and the excess supernate was cascaded to a crib. The first two tanks in the cascade (T-110 and $\mathrm{T}-111)$ received only these two wastes. Tank $\mathrm{T}-112$ received dilute decontamination waste (DW) and a mixture of liquid wastes in the late 1960s and early 1970s. These transfers would not have significantly altered the characteristics of the waste relative to the first two waste types. Tank T-110 is on the watch list for gas generation.

\subsubsection{Group XV - 2C, 5-6}

This three-tank group, located in the B Tank Farm of the 200 East Area, contains 516,000 gallons of waste. The majority of waste--511,000 gallons--is sludge. These three tanks also were connected in a three-tank cascade. The cascade was originally filled with $2 \mathrm{C}$ waste in the 1940s, cribbed in 1950, and refilled with $2 \mathrm{C}$ waste. The continuous overflow in B-112 was cribbed. The cascade began receiving 5-6 waste from B Plant in 1952 and fission products in 1963 . The cascade received B Plant low-level waste (BL) and ion exchange waste (IX) in the late 1960s and early 1970s, but these were mostly liquid in nature and are not considered significant contributors to the physical and chemical characteristics of the solids remaining in the tank, relative to the previous three wastes. Tank B-112 received EB and recycle from the ITS loop. This EB-ITS waste did not cause the formation of salt cake typically exhibited by this waste form. Seven cores from Tank B-110 were obtained in 1989 and 1990 as part of Phase 1A and 1B of the Waste Characterization Program. These core samples underwent extensive analytical testing and provide excellent data for physical and chemical characterization of this group. 


\subsubsection{Group XVI - R, RIX}

Group XVI consists of three SX farm tanks, which hold 368,000 gallons of waste. All of this waste is sludge. These tanks received REDOX high-level waste after they were released to operations in the mid- to late 1950 s. These tanks received only $R$ until the early 1970s, when RIX was introduced. In the mid- to late 1970s, these tanks received minor quantities of various waste types, mostly liquid in nature. Tank SX-114 received a small amount of EB waste but not in sufficient concentrations to catalyze crystal formation.

\subsubsection{Group XVII - 1C, CW}

This three-tank group contains 305,000 gallons of waste, the majority of which-303,000 gallons is sludge. No salt cake has been observed in these tanks. These tanks initially received $2 \mathrm{C}$ waste in 1947 . The cascade was then filled with $1 \mathrm{C}$ waste from 1948 until 1955 and then began receiving CW in large quantities. A large amount of solids accumulated from these three waste types. In the 1970s, a number oi different liquid wastes were transferred through these three, tanks, but these wastes did not affect the solids content to the degree of the previous three wastes.

\subsubsection{Group XVIII - CW, EB}

This three-tank group contains 204,000 gallons of waste, the vast majority of which is sludge; but 10,000 gallons of salt cake has formed in one of the tanks. These tanks also were connected in a three-tank cascade. The cascade was originally filled with MW in the 1940 s and, as was typical with MW, sluiced out in the early 1950s. The cascade then began receiving evaporated cladding waste $(\mathrm{CW})$. Apparently the $\mathrm{CW}$ was not concentrated to the point of salt cake formation because of the limited amount of this waste form observed in the tank. The cascade also received unconcentrated CW in the 1960s. These tanks received BL and IX in the 1970s, but these predominantly liquid wastes are not considered to have contributed significantly to the solids formation in the tank.

\subsubsection{Group XIX - CW, MIX}

This three-tank cascade currently holds 192,000 gallons of waste, most of which $(145,000$ gallons) is sludge. No salt cake has been observed in these tanks. The cascade was initially filled with MW in the 1940s and emptied in 1951. Tank T-101 received a small amount of TBP-scavenged waste from a plant pilot test of the process; this waste was then flushed from the tank. The cascade was again filled with $\mathrm{MW}$ in 1955 but emptied the following year. Tank T-101 is listed as a ferrocyanide tank, but this waste was removed, and the tank was effectively sluiced twice afterwards, so it is unlikely that any appreciable amount of ferrocyanide remains. The empty cascade was then filled with CW beginning in 1957. This single waste type remained until the early 1970s, when a mixture of liquid waste was flushed through this cascade. The liquid wastes are considered to have had only a limited impact on the characteristics of the solid waste remaining in the tank. 


\subsubsection{Group XX - CW}

These three 200-Series tanks from U Farm contain only 13,000 gallons of waste. The history of these tanks indicates that the predominant waste type is $\mathrm{CW}$. The insignificant amount of waste contained in these tanks makes this group virtually irrelevant.

\subsubsection{Group XXI-TBP,EB-ITS}

This pair of BY Farm tanks contains a combined total of 907,000 gallons of waste. The majority of this waste--771,000 gallons--is salt cake, while 87,000 gallons is sludge. Both tanks received MW before 1955 but were sluiced of their contents. Beginning in 1955, both tanks received TBP waste. Both tanks received quantities of CW in the early 1960 s and were connected to an ITS loop in the late 1960s. Tank BY-102 belonged to ITS-1, and BY-109 belonged to ITS-2. Despite being connected to different ITS loops (and operated by different principles), the solids remaining in the two tanks can be expected to be relatively similar. These tanks both received TBP and CW before ITS. The hardness of the salt cake will prohibit sampling until a hard cake sampler is developed.

\subsubsection{Group XXII - EB, TBP}

This pair of TX Farm tanks contains 481,000 gallons of waste, and all of it is salt cake. The processing history of these two tanks is slightly different; however, the major waste types are the same. Tank TX-108 received MW in the late 1940s, which was sluiced out in the early 1950s. A minor quantity of $R$ waste was introduced into this tank in the mid-1950s. On top of this $R$ heel, a substantial amount of TBP waste was added.

Tank TX-118 received $1 \mathrm{C}$ waste in the early $1950 \mathrm{~s}$. Most of this waste type was tiansferred out of the tank, and the TBP waste was added on top of this heel. In the late 1960s and early 1970s, significant quantities of EB from the 242-T Evaporator were added to both of these tanks, causing salt cake formation. Tank TX-118 is on the watch list because of transfers of ferrocyanide-scavenged waste.

\subsubsection{Group XXIII - SRS, SL-WASH}

Both of the tanks in this group are located in C Farm and contain 429,000 gallons of waste, the bulk of which--372,000 gallons--is sludge. This group received MW in the 1940s, but this waste was removed from these tanks in the early 1950s. The tanks were then filled with TBP waste. During the 1960s, these tanks received various quantities of $P$ and CW. In the early 1970s, these tanks received large quantities of a highly mixed liquid waste, which was later transferred out. This liquid probably did not greatly affect the solids. In 1976 and 1977, these tanks received a large transfer of strontium leached sludge (SRS), which greatly added to the solids volume in the tank. These tanks also received a large quantity of highlevel solids as suspended particulates from a sludge wasting campaign in the AR vault. These suspended solids settled in the tanks and are considered a significant contributor to the solids characteristics and high radioactivity. Both of the tanks were previously core sampled. Tank C-103 is on the watch list as an "organic" tank, because it has a separate organic liquid layer. Tank C-106 is on the same list as a "high heat" tank. 


\subsubsection{Group XXIV - 1C, EB-ITS}

The two BX Farm tanks contain 429,000 gallons of waste--152,000 gallons of salt cake and 257,000 gallons of sludge. Both of these tanks received 1C waste in the late 1940s and early 1950s. Tank BX-110 received some EB in the mid- to late 1950s. Both tanks received CW and IX wastes in the 1960s before receiving EB from one of the ITS loops. The physical forms of the waste, as reported by Hanlon (1990), are very different for these two tanks. The majority of BX-110 is sludge, and only 9,000 gallons $\left(\approx 3 \frac{114}{\mathrm{in}}\right.$.) is salt cake. Tank BX-111 exhibits a greater amount of salt cake (143,000 gallons) than sludge (68,000 gallons). These differences in the reported physical form might result from imprecise sludge measurements during the early history of these tanks, or it might be the consequence of real differences between the tanks. This question cannot be answered until one or both of the tanks has been core sampled.

\subsubsection{Group XXV - TBP}

This pair of TY Farm tanks contains 248,000 gallons of waste, all of which is sludge. These tanks had a very simple processing history; they received only one waste type--TBP. These tanks have been previously core sampled.

\subsubsection{Group XXVI - TBP, EB}

This pair of 200 West Area tanks hold a total of 215,000 gallons of waste, all of which is sludge. Although these tanks received an appreciable amount of evaporative bottoms (EB), the characteristic salt cake did not form.

\subsubsection{Group XXVII - TBP}

This pair of ferrocyanide tanks is located in TY Farm and contains 208,000 gallons of waste. The majority of waste--205,000 gallons--is sludge. No salt cake has been observed in these tanks. These tanks received TBP waste in the early 1950s, then during the mid-1950s, the supernate was transferred out and ferrocyanide-scavenged 1C waste placed on top of the TBP heel. These two waste types caused significant solids accumulation. During the 1960s and 1970s, a variety of waste was transferred into and out of these tanks. The solids accumulation did not substantially change during these transfers; therefore, these later transfers are not considered to have affected the physical and chemical characteristics of the solids already present in the tank. Both of these tanks have been previously sampled.

\subsubsection{Group XVIII - CCPLX, DSSF}

This group of two AX Farm tanks contains 151,000 gallons of waste, consisting of 40,000 gallons of salt cake and 9,000 gallons of sludge, with the remainder supernatant liquid. Both of these tanks were sluiced of their contents in 1977, leaving a 6,000-gallon heel of $P$ waste. The tanks then received wastes identified by unspecific waste names like concentrated complexed waste (CCPLX), double-shell slurry feed (DSSF), and evaporator feed (EVAP). Using such broad waste identifiers--based on suitability for further treatment, not waste source--precludes grouping by radioactive waste type. 


\subsubsection{Group XXIX - R, DIA}

This pair of assumed leaker tanks contains 148,000 gallons of waste, all of which is sludge. Tank U-104 initially received MW in the 1940s, but this waste type was sluiced from the tank in the early 1950s. Tank SX-113 was not released to operation until the mid-1950s. Both tanks exclusively received $R$ after 1958. Diatomaceous earth was added to both tanks after they were declared leakers, in an attempt to prevent the escape of liquid waste.

\subsubsection{Group XXX - Solitary Tanks (Ungrouped)}

Of the 149 SSTs, only 19 did not fall into groups based on radioactive waste types. These 19 tanks transcend almost every waste type and every tank farm in the 200 East and West Areas. They contain mostly sludge. These ungrouped tanks represent $2,461,000$ gallons of waste-- 69,000 gallons of salt cake and $2,377,000$ gallons of sludge. Several of these tanks have significunt quantities of waste in them, and others have relatively little waste. Many of these tanks might also be related to some of the groups previously described. 


\subsection{REFERENCES}

Adams, M. R, L. Jensen, and W. W. Schulz. September 1986. Preliminary Assessment of the TRAC Model as a Predictor of Key Radionuclide Inventories. RHO-RE-EV-89 P, Rockwell Hanford Operations, Richland, Washington.

Anderson, J. D. 1990. A History of the 200 Area Tank Farms. WHC-MR-0132, Westinghouse Hanford Company, Richland, Washington.

Morgan, L. G., W. W Schulz, M. R. Adams, and K. W. Owens. July 1988. Summary of Single-Shell Tank Waste Characterization: 1985 to 1987. WHC-EP-0075, Westinghouse Hanford Company, Richland, Washington.

Jungfleisch, F. M. 1984. TRAC: A Preliminary Estimation of the Waste Inventories in Hanford Tanks Through 1980. SD-WM-TI-057, Rockwell Hanford Operations, Richland, Washington.

Hanlon, B. M. 1990. Tank Farm Surveillance and Waste Status Summary Report for July 1990. WHC-EP-0182-28, Westinghouse Hanford Company, Richland, Washington. 


\section{APPENDIX A}

SORT ON RADIOACTIVE WASTE TYPE (SORWT) MODEL RESULTS 
PNL-9814 Rev. 1

SORT ON RADIOACTIVE WASTE TYPE MODEL RESULTS

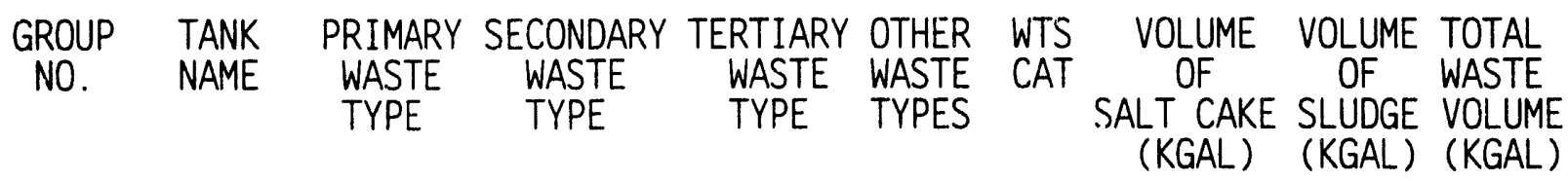

I. $R \quad E B$

22 TANKS

Gas Generating Subgroup

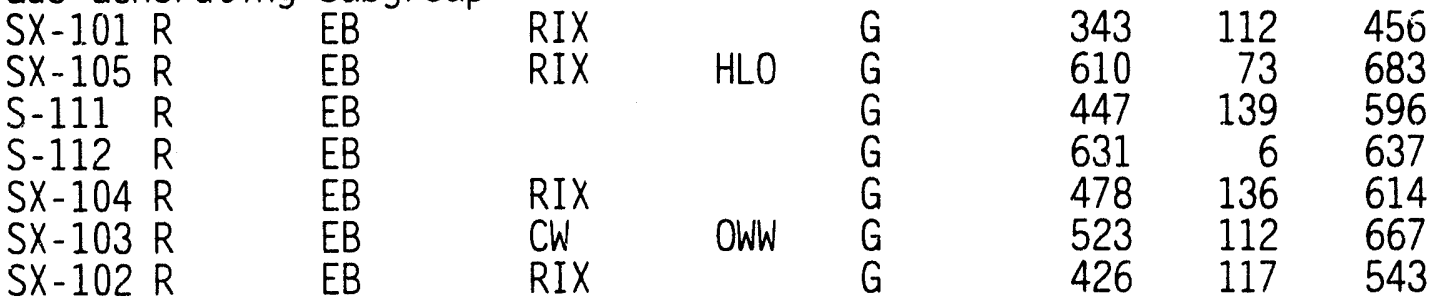

Organic Tank Subgroup

TX-105 R

$S X-106 R$

$E B$

$E B$

S-102 R

$E B$

$\begin{array}{lr}\text { MIX } & 0 \\ \text { RIX } & \text { HLO-MX } \\ \text { DSSF } & O G\end{array}$

$\begin{array}{lll}609 & 0 & 609\end{array}$

$465 \quad 12 \quad 538$

Non-Pub7ic Law 101-510 Subgroup

$\begin{array}{ll}\text { S-110 } & R \\ \text { S-108 } & R \\ \text { S-107 } & R \\ \text { S-106 } & R \\ \text { S-105 } & R \\ \text { S-103 } & R \\ \text { S-101 } & R \\ \text { S-109 } & R \\ \text { TX-106 } & R \\ \text { TX-104 } & R \\ T X-107 & R \\ \text { TX-102 } & R\end{array}$

$E B$
$E B$
$E B$
$E B$
$E B$
$E B$
$E B$
$E B$
$E B$
$E B$
$E B$
$E B$

MIX

CW

IX-MIX $\begin{aligned} & N \\ & N \\ & N \\ & N \\ & N\end{aligned}$

$561 \quad 131 \quad 692$

$600 \quad 4 \quad 604$

$\begin{array}{lll}69 & 293 & 368\end{array}$

$511 \quad 32 \quad 543$

$\begin{array}{lll}454 & 2 & 456\end{array}$

$\begin{array}{lll}221 & 10 & 248\end{array}$

$\begin{array}{lll}171 & 244 & 427\end{array}$

$\begin{array}{lll}555 & 13 & 568\end{array}$

$453 \quad 0 \quad 453$

$\begin{array}{lll}64 & 0 & 65\end{array}$

$\begin{array}{rrr}35 & 0 & 36 \\ 113 & 0 & 113\end{array}$

Group Subtota 1

$8884 \quad 1440 \quad 10465$

II. $\mathrm{EB} \quad \mathrm{IC}$

10 TANKS

TX-117 EB

$T X-116$ EB

$T Y-102$ EB

TX-113 EB

B-105 EB

$\mathrm{T} X-112 \mathrm{~EB}$

MIX

MIX

N

$T X-111 E B$

TX-114 EB

TX-110 EB

TX-109 EB

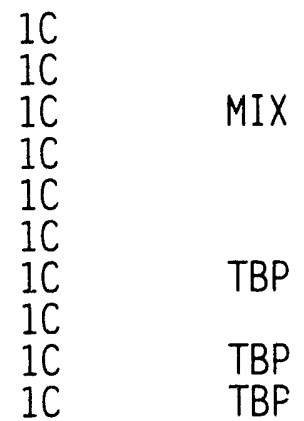

$N$
$N$
$N$
$N$
$N$
$N$
$N$
$N$
$N$
$N$

Group Subtotal

$\begin{array}{rrrrr} & N & 626 & 0 & 626 \\ & N & 631 & 0 & 631 \\ \text { MIX } & N & 64 & 0 & 64 \\ & N & 607 & 0 & 607 \\ & N & 266 & 40 & 306 \\ & N & 649 & 0 & 649 \\ \text { TBP } & N & 370 & 0 & 370 \\ & N & 535 & 0 & 535 \\ \text { TBP } & N & 462 & 0 & 462 \\ \text { TBF } & N & 384 & 0 & 384 \\ & & & & \\ & & & & \\ & & & & \end{array}$


PNL-9814 Rev. 1

SORT ON RADIOACTIVE WASTE TYPE MODEL RESULTS

GROUP TANK PRIMARY SECONDARY TERTIARY OTHER WTS VOLUME VOLUME TOTAL

NO. NAME WASTE WASTE WASTE WASTE CAT OF OF WASTE TYPE TYPE TYPE TYPES SALT CAKE SLUDGE VOLUME (KGAL) (KGAL) (KGAL)

III. TBP.F EB-ITS

10 TANKS

$\begin{array}{ll}\text { BY-105 TBP-F } & \text { EB-ITS } \\ \text { BY-104 TBP-F } & \text { EB-ITS } \\ \text { BY-103 TBP-F } & \text { EB-ITS } \\ \text { BY-106 TBP-F } & \text { EB-ITS } \\ \text { BY-108 TBP-F } & \text { EB-ITS } \\ \text { BY-110 TBP-F } & \text { EB-ITS } \\ \text { BY-101 TBP-F } & \text { EB-ITS } \\ \text { BY-107 TBP-F } & \text { EB-ITS } \\ \text { BY-112 TBP-F } & \text { EB-ITS } \\ \text { BY-111 TBP-F } & \text { EB-ITS } \\ \text { Group Subtotal } & \end{array}$

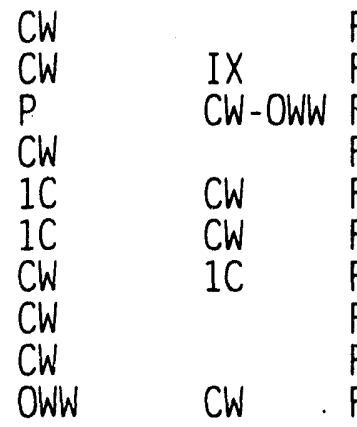

$459 \quad 44 \quad 503$

$366 \quad 40 \quad 406$

$395 \quad 5 \quad 400$

$547 \quad 95 \quad 642$

$\begin{array}{lll}74 & 154 & 228\end{array}$

$\begin{array}{lll}295 & 103 & 398\end{array}$

$\begin{array}{lll}278 & 109 & 387\end{array}$

$206 \quad 60 \quad 266$

$286 \quad 5 \quad 291$

$\begin{array}{lll}438 & 21 & 459\end{array}$

$3344 \quad 636 \quad 3980$

IV. TBP CW

9 TANKS

Non-Public Law 101-510 Subgroup

\begin{tabular}{|c|c|c|c|}
\hline $\begin{array}{ll}B X-102 & T B P \\
B X-106 & T B P \\
B X-101 & T B P \\
B X-104 & T B P \\
B X-101 & T B P \\
B X-103 & T B P \\
B X-105 & T B P \\
B X-109 & T B P \\
B X-108 & T B P\end{array}$ & $\begin{array}{l}C W \\
C W \\
C W \\
C W \\
C W \\
C W \\
C W \\
C W \\
C W\end{array}$ & $\begin{array}{l}B L \\
E B-I X \\
B L \\
I X \\
P \\
\text { OWW } \\
I X \\
I C \\
I C\end{array}$ & $\begin{array}{l}\text { DIA } \\
\text { BL } \\
\text { IX } \\
\text { R } \\
\text { OWh } \\
\text { MIX } \\
\text { EB } \\
\text { IX } \\
\text { IX }\end{array}$ \\
\hline
\end{tabular}

Group Subtota 1

V. 224

8 TANKS

$\mathrm{T}-201 \quad 224$

T-203 224

$T-202 \quad 224$

B-201 224

B-202 224

B-203 224

B-204 224

T-204 224

$\begin{array}{rrrr}N & 0 & 28 & 29 \\ N & 0 & 35 & 35 \\ N & 0 & 21 & 21 \\ N & 0 & 28 & 28 \\ N & 0 & 28 & 28 \\ N & 0 & 50 & 51 \\ N & 0 & 49 & 50 \\ N & 0 & 38 & 38 \\ & 0 & 277 & 280\end{array}$

Group Subtota1

$3 \quad 656 \quad 687$ 
PNL-9814 Rev. 1

SORT ON RADIOACTIVE WASTE TYPE MODEL RESULTS

GROUP TANK PRIMARY SECONDARY TERTIARY OTHER WTS VOLUME VOLUME TOTAL

NO. NAME WASTE WASTE WASTE WASTE CAT OF OF WASTE TYPE TYPE TYPE TYPES SALT CAKE SLUDGE VOLUME

VI. $\quad \mathrm{R}$

7 TANKS

High Heat Subgroup

$S X-112 R$

$S X-108 R$

$S X-107 R$

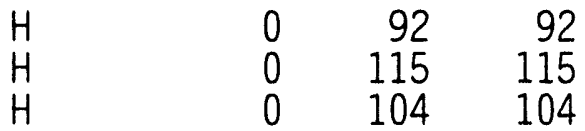

Gas Generating Subgroup

SX-109 R

GH $\quad 0 \quad 250 \quad 250$

Non-Public Law 101-510 Subgroup (KGAL) (KGAL) (KGAL)

SX-115 R

$\mathrm{U}-101 \quad \mathrm{R}$

S-104 R

N

$\mathrm{N}$

$\begin{array}{lll}0 & 12 & 12 \\ 0 & 22 & 25\end{array}$

Group Subtotal

$\begin{array}{lll}0 & 293 & 294\end{array}$

EB $R$

5 TANKS

Gas Generating Subgroup

U-103 EB R MIX

G

$\begin{array}{lll}423 & 32 & 468\end{array}$

Organic Tank Subgroup

U-106 EB

U-111 EB

$B L$
$1 C$

$\mathrm{PL}$

$0 \quad 888 \quad 892$

Non-Public Law 101-510 Subgroup

$U-102 \quad E B$

TX-115 EB

CW DW N

$313 \quad 43 \quad 374$

Group Subtotal

$\begin{array}{lll}1864 & 127 \quad 2037\end{array}$

VIII. TBP -F IC

5 TANKS

$\begin{array}{lllllllrr}\text { C-111 } & \text { TBP-F } & \text { IC } & \text { CW } & \text { HS } & F & 0 & 57 & 57 \\ \text { C-112 } & \text { TBP-F } & \text { IC } & \text { CW } & \text { IX } & \text { F } & 0 & 109 & 109 \\ \text { T-107 TBP-F } & \text { IC } & \text { CW } & \text { IX } & \text { F } & 0 & 171 & 180 \\ \text { C-109 TBP-F } & \text { IC } & \text { CW } & \text { IX } & \text { F } & 0 & 62 & 66 \\ \text { C-108 TBP-F } & \text { IC } & \text { CW } & \text { OWW } & \text { F } & 0 & 66 & 66 \\ \text { Group Subtota1 } & & & & & 0 & 465 & 478\end{array}$


PNL-9814 Rev. 1

SORT ON RADIOACTIVE WASTE TYPE MODEL RESULTS

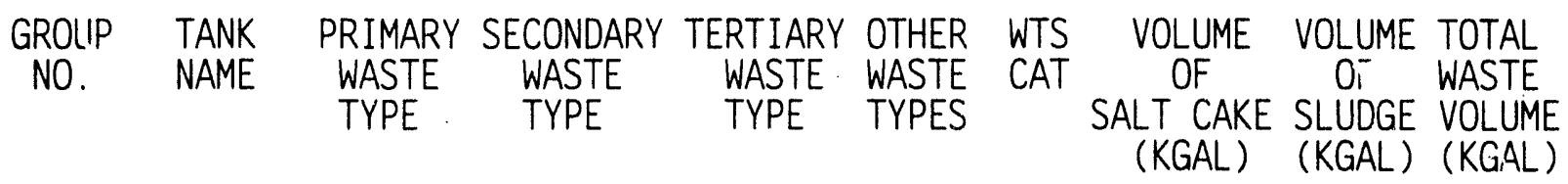

IX. DSSF NCPLX

4 TANKS

A-101 DSSF NCPLX EVAP

AX-101 DSSF NCPLX EVAP

$\begin{array}{llll}G & 950 & 3 & 953 \\ G & 745 & 3 & 748\end{array}$

A-103 DSSF NCPLX EVAP

A-102 DSSF NCPLX EVAP

N

$\begin{array}{lll}0 & 366 & 371\end{array}$

Group Subtotal

$\begin{array}{lll}1717 & 387 & 2113\end{array}$

$X$. $E B \quad C W$

\section{TANKS}

$\begin{array}{llll}\text { U-105 } & E B & C W & R \\ \text { U-108 } & E B & C W & \text { MIX } \\ \text { U-109 } & E B & C W & R \\ \text { U-107 } & E B & C W & \text { MIX } \\ \text { Group Subtotal } & & \end{array}$

XI. $\quad$ IC TBP

OWW
CW
EB
HLO

$\begin{array}{ll}C-110 & 1 C \\ B X-107 & 1 C\end{array}$

TBP

TBP

$\mathrm{T}-108 \quad 1 \mathrm{C}$

TBP

B-106 1C

TBP

Group Subtotal

$\begin{array}{rrrr}G & 349 & 32 & 418 \\ G & 415 & 29 & 468 \\ G & 396 & 48 & 463 \\ 0 & 360 & 15 & 406 \\ & 1520 & 124 & 1755\end{array}$

\section{TANKS}

$\begin{array}{lrrrr}\text { EB-IX } & N & 0 & 196 & 201 \\ \text { IX } & N & 0 & 348 & 348 \\ \text { HLO } & N & 0 & 44 & 44 \\ \text { MIX } & N & 0 & 116 & 117 \\ & & & & \\ & & 0 & 704 & 710\end{array}$

XII. $\quad 1 C \quad E B$

\section{TANKS}

$\begin{array}{ll}B-108 & 1 C \\ B-107 & 1 C \\ B-109 & 1 C \\ B X-112 & 1 C\end{array}$

$\begin{array}{ll}E B & C W \\ E B & C W \\ E B & C W \\ E B & C W\end{array}$

$\begin{array}{ll}\text { IX-TBP } & N \\ \text { TBP } & N \\ \text { IX } & N \\ \text { IX } & N\end{array}$

$\begin{array}{rrr}0 & 94 & 94 \\ 0 & 164 & 165 \\ 0 & 127 & 127 \\ 0 & 167 & 167\end{array}$

Group Subtotal

$0 \quad 552 \quad 553$ 
PNL-9814 Rev. 1

SORT ON RADIOACTIVE WASTE TYPE MODEL. RESULTS

GROUP TANK PRIMARY SECONDARY TERTIARY OTHER WTS VOLUME VOLUME TOTAL

NO. NAME WASTE WASTE WASTE WASTE CAT OF OF WASTE TYPE TYPE TYPE TYPES SALT CAKE SLUDGE VOLUME (KGAL) (KGAL) (KGAL)

XIII. HS

4 TANKS

$\begin{array}{ll}\mathrm{C}-204 & H S \\ \mathrm{C}-202 & H S \\ \mathrm{C}-201 & H S \\ \mathrm{C}-203 & H S\end{array}$

Group Subtota1

XIV. $\quad 2 C \quad 224$

$\begin{array}{lll}T-110 & 2 C & 224 \\ T-112 & 2 C & 224\end{array}$

Organic Tank Subgroup

T-111 2C 224

Group Subtota 1

$\begin{array}{lll}X V & 2 C \quad 5.6\end{array}$

$\begin{array}{ll}\text { B- } 112 & 2 \mathrm{C} \\ \mathrm{B}-110 & 2 \mathrm{C} \\ \mathrm{B}-111 & 2 \mathrm{C}\end{array}$

5-6

$5-6$

5-6

Group Subtotal

XVI. $R \quad R I X$

$S X-110 R$

$S X-111 R$

$S X-114 R$

Group Subtota1

RIX MIX

RIX

RIX

$E B$

XVII. $1 \mathrm{C} \quad \mathrm{CW}$

$\begin{array}{ll}U-110 & 1 C \\ T-105 & 1 C \\ T-106 & 1 C\end{array}$

$C W$
$C W$
$C W$

Group Subtotal

DW

$R$
$2 C$
$2 C$
$N$
$N$
$N$
$N$

$\operatorname{MIX} \stackrel{\mathrm{G}}{\mathrm{N}}$

$\begin{array}{rrr}0 & 376 & 379 \\ 0 & 60 & 67\end{array}$

0

$\begin{array}{lll}0 & 456 & 458\end{array}$

0
$892 \quad 904$

3 TANKS

$\begin{array}{ll}\text { EB-ITS } & N \\ \text { IX } & N \\ \text { IX } & N\end{array}$

$\begin{array}{rrr}0 & 30 & 33 \\ 0 & 245 & 246 \\ 0 & 236 & 237\end{array}$

$0 \quad 511 \quad 516$

\section{TANKS}

MIX

$\stackrel{H}{H}$

$\begin{array}{rrr}0 & 62 & 62 \\ 0 & 125 & 125 \\ 0 & 181 & 181\end{array}$

$\begin{array}{lll}0 & 368 & 368\end{array}$

\section{TANKS}

$\begin{array}{ll}\text { LW } & N \\ \text { BL-IX } & N \\ \operatorname{MIX} & N\end{array}$

$\begin{array}{lll}0 & 186 & 186\end{array}$

$\begin{array}{lll}0 & 98 & 98 \\ 0 & 19 & 21\end{array}$

$\begin{array}{lll}0 & 303 & 305\end{array}$ 
PNL-9814 Rev. 1

SORT ON RADIOACTIVE WASTE TYPE MODEL RESULTS

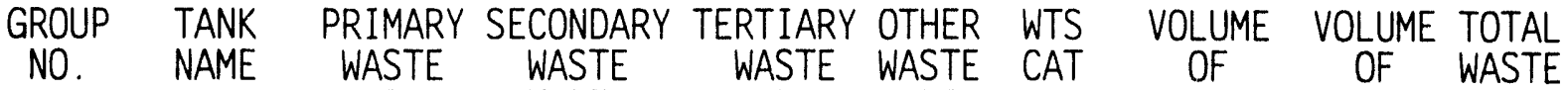

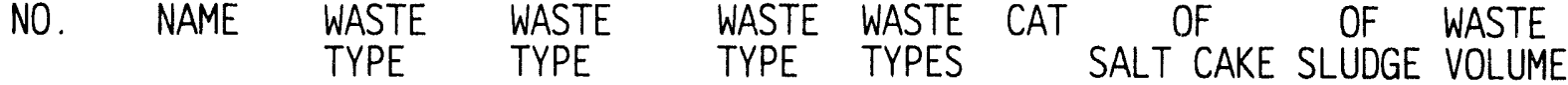
(KGAL) (KGAL) (KGAL)

XVIII. CW EB

3 TANKS

\begin{tabular}{|c|c|c|c|c|c|c|}
\hline $\begin{array}{ll}B-102 & C W \\
B-101 & C W \\
B-103 & C W\end{array}$ & $\begin{array}{l}E B \\
E B \\
E B\end{array}$ & $\begin{array}{l}B L \\
B L \\
I X\end{array}$ & MIX & $\begin{array}{l}N \\
N \\
0\end{array}$ & $\begin{array}{r}10 \\
0 \\
0\end{array}$ & $\begin{array}{r}18 \\
113 \\
59\end{array}$ \\
\hline Group Subt & & & & & 10 & 190 \\
\hline
\end{tabular}

XIX. CW MIX

\section{TANKS}

$\begin{array}{lll}T-103 & C W & \text { MIX } \\ \text { T-102 } & \text { CW } & \text { MIX IX }\end{array}$

$\begin{array}{rrrr}F & 0 & 103 & 133 \\ N & 0 & 23 & 27 \\ N & 0 & 19 & 32 \\ & 0 & 145 & 192\end{array}$

$X X . \quad C W$

3 TANKS

$\begin{array}{ll}U-201 & C W \\ U-203 & C W \\ U-202 & C W\end{array}$

$\begin{array}{llll}N & 0 & 4 & 5 \\ N & 0 & 2 & 3 \\ N & 0 & 4 & 5\end{array}$

Group Subtotal

$\begin{array}{lll}0 & 10 & 13\end{array}$

XXI. TBP EB-ITS

\section{TANKS}

$\begin{array}{llllllll}\text { BY-102 TBP } & \text { EB-ITS } & \text { CW } & \text { 1C } & \text { N } & 417 & 0 & 432 \\ \text { BY-109 TBP } & \text { EB-ITS } & \text { CW } & \text { MW } & \text { N } & 354 & 87 & 475 \\ \text { Group Subtotal } & & & & & 771 & 87 & 907\end{array}$

XXII. EB TBP

2 TANKS

$\begin{array}{llllllll}\text { TX-118 EB } & \text { TBP } & \text { CW } & \text { 1C } & \text { FO } & 347 & 0 & 347 \\ \text { TX-108 EB } & \text { TBP } & \text { R } & & \text { N } & 134 & 0 & 134 \\ \text { Group Subtotal } & & & & & 481 & 0 & 481\end{array}$

XXIII. SRS SLUICE

\section{TANKS}
C-106 SRS
SR-WASH
TBP $\quad H$
$\begin{array}{lll}0 & 197 & 229 \\ 0 & 175 & 200\end{array}$
Group Subtotal
$\begin{array}{lll}0 & 372 \quad 429\end{array}$ 
PNL-9814 Rev. 1

SORT ON RADIOACTIVE WASTE TYPE MODEL RESULTS

GROUP TANK PRIMARY SECONDARY TERTIARY OTHER WTS VOLUME VOLUME TOTAL

NO. NAME WASTE WASTE WASTE WASTE CAT OF OF WASTE

TYPE TYPE TYPE TYPES

SALT CAKE SLUDGE VOLUME

(KGAL) (KGAL) (KGAL)

XXIV. IC EB-ITS

2 TANKS

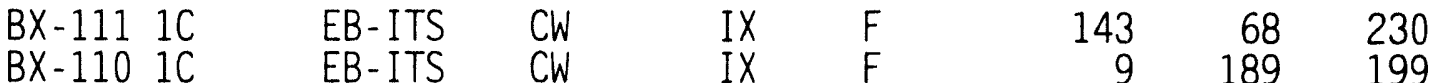

Group Subtota1

$152 \quad 257 \quad 429$

$X X V . \quad T B P$

2 TANKS

TY-106 TBP

TY-105 TBP

$\begin{array}{rrrr}N & 0 & 17 & 17 \\ N & 0 & 231 & 231\end{array}$

Group Subtotal

$0 \quad 248 \quad 248$

$X X V I$. TBP EB

2 TANKS

$\begin{array}{lll}T-109 & \text { TBP } & \text { EB } \\ T X-103 & \text { TBP } & \text { EB }\end{array}$

Group Subtotal

$\begin{array}{rrrr}N & 0 & 58 & 58 \\ N & 0 & 157 & 157 \\ & & & \\ & & 215 & 215\end{array}$

$X X V I I$. TBP $1 C \cdot F$

2 TANKS

$\begin{array}{llllllll}\text { TY-104 TBP } & \text { IC-F } & \text { DW } & \text { MIX-R } & F & 0 & 43 & 46\end{array}$

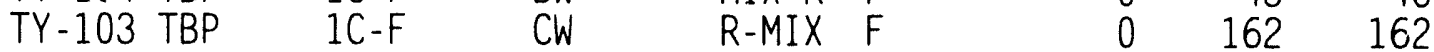

Group Subtotal

$0 \quad 205208$

XXVIII. CCPLX DSSF

AX-103 CCPLX DSSF EVAP

AX-102 CCPLX DSSF EVAP

$\stackrel{G}{N}$

$\begin{array}{rrr}11 & 2 & 112 \\ 29 & 7 & 39\end{array}$

Group Subtota1

$\begin{array}{lll}40 & 9 & 151\end{array}$

XXIX. R DIA

2 TANKS

$\begin{array}{lll}U-104 & R & \text { DIA } \\ S X-113 & R & \text { DIA }\end{array}$

$\begin{array}{rrrr}N & 0 & 122 & 122 \\ N & 0 & 26 & 26\end{array}$

Group Subtotal

$\begin{array}{lll}0 & 148 & 148\end{array}$ 
PNL-9814 Rev. 1

SORT ON RADIOACTIVE WASTE TYPE MODEL RESULTS

GROUP TANK PRIMARY SECONDARY TERTIARY OTHER WTS VOLUME VOLUME TOTAL

NO. NAME WASTE WASTE WASTE WASTE CAT OF OF WASTE

$$
\text { TYPE TYPE TYPE TYPES SALT CAKE SLUDGE VOLUME }
$$

(KGAL) (KGAL) (KGAL)

XXX. SOLITARY TANKS (UNGROUPED) 14 TANKS

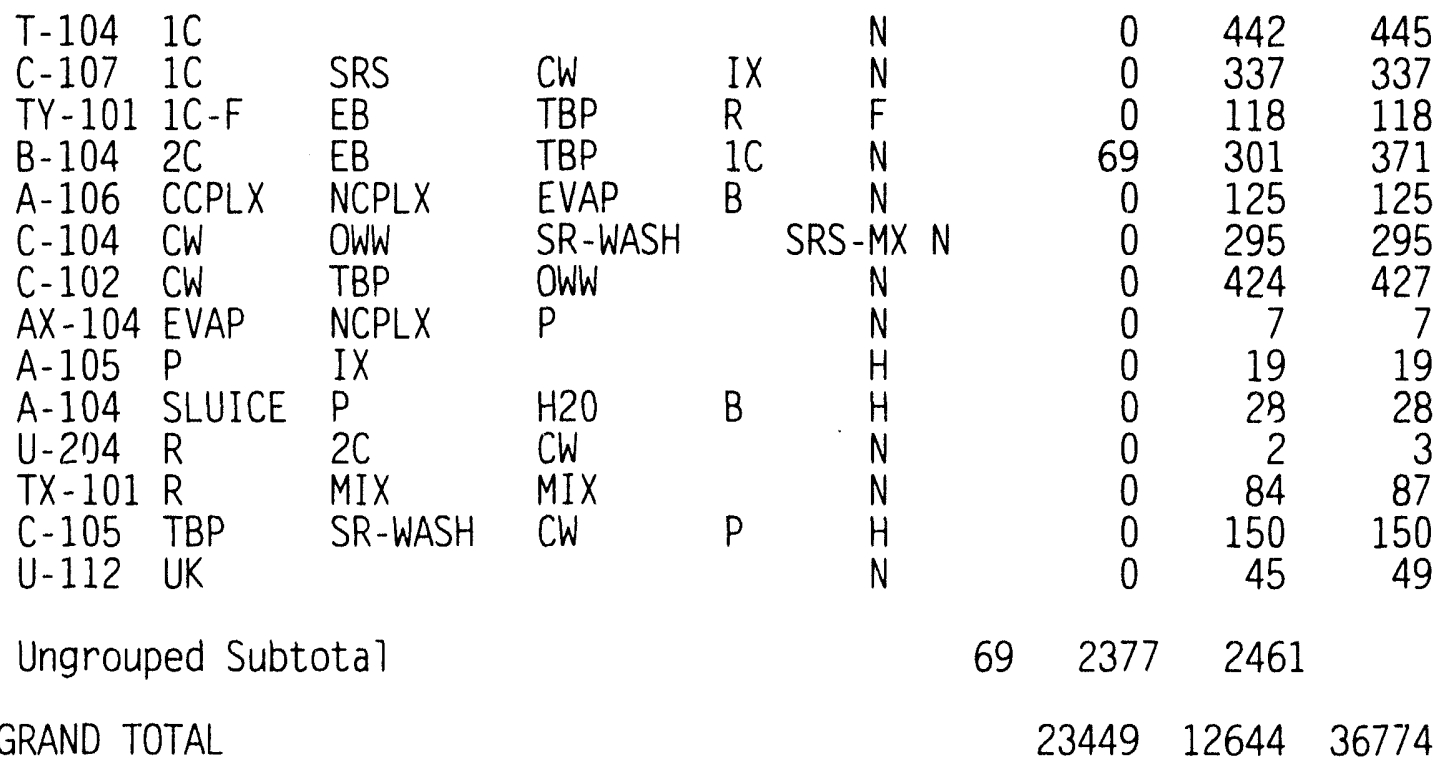




\section{APPENDIX B}

\section{WASTE TYPES IN HANFORD SITE SINGLE-SHELL TANKS}


PNL-9814 Rev. 1

PREFACE

\section{A BRIEF DESCRIPTION OF SINGLE-SHELL TANK WASTE TYPES}

This appendix contains a draft document that was never completed. The initial work was performed by Glen Lucas, a Westinghouse Hanford Company temporary employee. A substantial amount of data are presented, and most of the results are believed to be accurate. 
PNL-9814 Rev. 1

\section{APPENDIX B}

\section{WASTE TYPES IN HANFORD SITE SINGLE-SHELL TANKS}

This appendix summarizes available information that describes wastes in the Hanford Site single-shell tanks (SST). The complexity of the waste-generating processes, the waste transfers from generating facilities to SSTs, and the transactions between SSTs severely compromises the completeness and accuracy of the information contained in this appendix. These data, however, provide information to support tank categorization before actual characterization of SST waste.

From 1944 until 1980, 149 SSTs received chemical wastes from defense activities at the Hanford Site. Over this time period, many different waste types were produced from several processing plants.

The characterizations of waste types contained in this report were taken from a wide variety of sources. Compositions of the primary waste streams from two main extraction processes, bismuth phosphate $\left(\mathrm{BiPO}_{4}\right)$ and reduction oxidation (REDOX), as well as waste from the uranium extraction process at $U$ Plant, were obtained from process flow sheets. For the plutonium-uranium extraction (PUREX) and B Plant waste fractionization processes, published reports of waste compositions were relied upon because of the complex process chemistry and several changes in flow sheets. The low-level waste and flush waste compositions are difficult to specify but they can be assumed to be very dilute. In general, most low-level waste was sent to the cribs; only a small amount was sent to the SSTs. For the various campaigns to extract cesium and strontium (and in some cases other fission products), waste compositions were taken from process flow sheets when available. Some caution must be taken in evaluating the results because of several sources of error, including variability of the feed material, changes in process flow sheets, and the presence or absence of diluting streams such as wash wastes. Laboratory wastes from three laboratories operating at the Hanford Site also went into the SSTs; the composition of these wastes is unknown.

Not all of the named waste types have a unique point of origin. Some wastes result from evaporation of wastes already contained in SSTs, and other wastes are merely new names assigned to old wastes to reflect their suitability for further processing, including evaporation. During the early history of the Hanford Site, there was little interest in determining the composition of chemical waste streams, and little or no attempt was made to segregate wastes from different processes. The overriding concern during this period was to minimize waste volume to conserve space in the SSTs. To this end, from the early 1950s, waste in the SSTs was extensively subjected to evaporation. In the evaporators, supernatant liquids from the waste tanks were heated until a slurry was formed; this slurry was returned to the tanks, where a solid salt cake precipitated. Residual supernatant liquors were pumped to other tanks and re-evaporated. In another method, heaters were placed directly in the tanks and the wastes were evaporated without any transfers.

Because of the detection of leaks in several of the SSTs in the 1970s, it became necessary to reduce SST liquid wastes to a solid form or transfer them to the newly constructed double-shell tanks (DST). At this time, SST supernatant liquids were given 
designations according to the presence or absence of organic complexants and the suitability of the waste for further evaporation. For example, complexant concentrate (CC) waste was considered unsuitable for further evaporation at the SSTs because it was thought that the organic complexants might form a gel, making the waste difficult to pump. In contrast, evaporator feed (EF) was relatively dilute supernatant liquid that was suitable for evaporation. Terminal and residual liquors--waste types TL, HDRL, and RESD--should not be further evaporated at the SSTs because they would precipitate 1) fine aluminate solids that would settle and drain poorly or 2) deliquescent $\mathrm{NaOH}$ solids that would take up moisture from the air and redissolve. These waste types, designated double-shell slurry feed (DSSF), were pumped to the DSTs and then evaporated into a slurry. Because of the DSTs' secure construction, they were deemed suitable to accept liquids, suspended solids, and poorly draining slurries for indefinite storage. 
PNL-9814 Rev. 1

\section{WASTE DESCRIPTIONS}

The following are brief descriptions and chemical compositions, where available, of 49 waste types discharged to the SSTs.

1. B. High-level waste from waste fractionization process at B Plant starting in 1967.

Approximate Composition

\begin{tabular}{|l|l|}
\hline Element/isotope & \multicolumn{1}{|c|}{$\mathrm{mol} / \mathrm{L}$} \\
\hline $\mathrm{Al}$ & 0.079 \\
\hline $\mathrm{Ba}$ & 0.000032 \\
\hline $\mathrm{Ca}$ & 0.0001 \\
\hline $\mathrm{Cr}$ & 0.002 \\
\hline $\mathrm{C}_{6} \mathrm{H}_{9} \mathrm{O}_{7}$ (citrate) & 0.12 \\
\hline $\mathrm{Fe}$ & 0.029 \\
\hline $\mathrm{Mn}$ & 0.00029 \\
\hline $\mathrm{Na}$ & 1.29 \\
\hline $\mathrm{Ni}$ & 0.002 \\
\hline${ }^{106} \mathrm{Ru}$ & 0.000003 \\
\hline $\mathrm{Pu}$ & 0.000001 \\
\hline $\mathrm{NO}{ }_{3}$ & 1.27 \\
\hline $\mathrm{Tc}$ & 0.000048 \\
\hline $\mathrm{U}$ & 0.0029 \\
\hline $\mathrm{Zr}$ & 0.000048 \\
\hline
\end{tabular}

2. B Plant Elush (BFSH). Flush water from the B Plant during the time of the $\mathrm{BiPO}_{4}$ process in the 1950s.

3. BIX. This is a misprint for RIX. 
4. BL. Low-level waste from the waste fractionization plant beginning in 1968.

Typical Composition

\begin{tabular}{|l|l|}
\hline \multicolumn{1}{|c|}{ Element/isotope } & $\mathrm{mol} / \mathrm{L}$ \\
\hline $\mathrm{Al}$ & 0.55 \\
\hline $\mathrm{C}_{6} \mathrm{H}_{5} \mathrm{O}_{7}$ (citrate) & 0.92 \\
\hline $\mathrm{Ca}$ & 0.000005 \\
\hline $\mathrm{CO}_{3}$ & 2.61 \\
\hline $\mathrm{Mn}$ & 0.0029 \\
\hline $\mathrm{Na}$ & 5.55 \\
\hline $\mathrm{Ni}$ & 0.0092 \\
\hline $\mathrm{NO}{ }_{3}$ & 5.28 \\
\hline $\mathrm{Pb}$ & 0.014 \\
\hline $\mathrm{Pu}$ & 0.00087 \\
\hline $\mathrm{SiO}{ }_{3}$ & 0.0029 \\
\hline $\mathrm{U}$ & 0.37 \\
\hline
\end{tabular}

5. BLEB. Evaporator bottoms where B Plant low-level waste was the feed material.

6. BNW. Laboratory waste from Pacific Northwest Laboratory.

7. CARB. Organic wash waste from the PUREX Plant before 1963, using sodium carbonate solution.

Approximate Composition
\begin{tabular}{|l|c|}
\hline \multicolumn{1}{|c|}{ Element/isotope } & $\mathrm{mol} / \mathrm{L}$ \\
\hline $\mathrm{CO}_{3}$ & 0.21 \\
\hline $\mathrm{Na}$ & 0.43 \\
\hline $\mathrm{NO}_{3}$ & 0.07 \\
\hline $\mathrm{UO}_{2}$ & 0.03 \\
\hline
\end{tabular}


PNL-9814 Rev. 1

8. Complexant Concentrate (CCPL or $\mathrm{CC}$ ). Contains a high concentration of organic complexants such as HEDTA, EDTA, and citric acid as a result of B Plant processing and subsequent evaporation. Any further concentration of this waste would cause the complexants to form a gel that would not be pumpable nor considered suitable for storage in SSTs. The given composition is an average of sampled tanks.

Average Composition

\begin{tabular}{|l|l|}
\hline Element/isotope & $\mathrm{mol} / \mathrm{L}$ \\
\hline $\mathrm{Al}$ & 0.38 \\
\hline $\mathrm{Ba}$ & 0.0001 \\
\hline $\mathrm{Ca}$ & 0.013 \\
\hline $\mathrm{Cd}$ & 0.00062 \\
\hline $\mathrm{Cl}$ & 0.05 \\
\hline $\mathrm{CO}_{3}$ & 0.96 \\
\hline $\mathrm{Cr}$ & 0.0046 \\
\hline $\mathrm{Cu}$ & 0.00032 \\
\hline $\mathrm{F}$ & 0.12 \\
\hline $\mathrm{Fe}$ & 0.023 \\
\hline $\mathrm{K}$ & 0.032 \\
\hline $\mathrm{La}$ & 0.00065 \\
\hline $\mathrm{Mg}$ & 0.0012 \\
\hline $\mathrm{Mn}^{\mathrm{Ma}}$ & 0.0016 \\
\hline $\mathrm{Mo}$ & 0.003 \\
\hline $\mathrm{Na}^{\mathrm{Zr}}$ & 7.3 \\
\hline $\mathrm{Ni}^{\mathrm{Na}}$ & 0.006 \\
\hline $\mathrm{NO}_{2}$ & 0.78 \\
\hline $\mathrm{NO}{ }_{3}$ & 2.7 \\
\hline $\mathrm{OH}$ & 0.36 \\
\hline $\mathrm{Pb}$ & 0.0012 \\
\hline $\mathrm{PO}{ }_{4}$ & 0.026 \\
\hline $\mathrm{Si}$ & 0.0031 \\
\hline $\mathrm{SO}{ }_{4}$ & 0.09 \\
\hline $\mathrm{Zn}$ & 0.0006 \\
\hline & 0.0013 \\
\hline
\end{tabular}


PNL-9814 Rev. 1

9. Cesium Feed (CE). Small quantities of this waste were put into Tank C-105 in 1976. It was a PUREX or PUREX sludge supernate. For a typical composition; see waste type PSS.

10. Complexed Waste (CPLX). Dilute waste material containing relatively high concentrations of organic chelating agents such as EDTA and HEDTA from the B Plant waste fractionization process. This waste type is defined as containing at least $10 \mathrm{~g} / \mathrm{L}$ organic material, or $100 \mathrm{mCi} / \mathrm{g}$ radionuclides. This is a later designation (post-1976) that does not reflect the bulk composition or point of origin of the waste, but merely re-labels all the waste in a tank according to the presence or absence of B Plant complexants.

Typical Composition of Tank 102-AX

\begin{tabular}{|l|l|}
\hline \multicolumn{1}{|c|}{ Element/isotope } & $\mathrm{mol} / \mathrm{L}$ \\
\hline $\mathrm{Al}$ & 0.1 \\
\hline $\mathrm{CO}_{3}$ & 0.5 \\
\hline $\mathrm{F}$ & 0.007 \\
\hline $\mathrm{Na}$ & 2.7 \\
\hline $\mathrm{NO}_{2}$ & 0.27 \\
\hline $\mathrm{NO}_{3}$ & 0.72 \\
\hline $\mathrm{OH}$ & 0.25 \\
\hline $\mathrm{PO}_{4}$ & 0.014 \\
\hline $\mathrm{SO}_{4}$ & 0.176 \\
\hline
\end{tabular}


11. CW. Waste produced at the PUREX Plant from dissolution of zircaloy (after 1964) or aluminum fuel cladding. The zircaloy cladding was dissolved in an ammonium/fluoride, ammonium nitrate solution. The aluminum cladding was dissolved in a sodium nitrate/sodium hydroxide solution.

$\begin{gathered}\text { Approximate Composition - } \\
\text { Zircaloy Cladding }\end{gathered}$
\begin{tabular}{|l|l|}
\hline Element/isotope & $\mathrm{mol} / \mathrm{L}$ \\
\hline $\mathrm{F}$ & 1.01 \\
\hline $\mathrm{Na}$ & 1.4 \\
\hline $\mathrm{NO}_{3}$ & 0.02 \\
\hline $\mathrm{OH}$ & 0.37 \\
\hline $\mathrm{Pu}$ & 0.0006 \\
\hline $\mathrm{U}$ & 0.0008 \\
\hline $\mathrm{ZrO}_{2}$ & 0.15 \\
\hline
\end{tabular}

Aluminum Cladding

\begin{tabular}{|l|l|}
\hline Element/isotope & $\mathrm{mol} / \mathrm{L}$ \\
\hline $\mathrm{Al}$ & 1 \\
\hline $\mathrm{Na}$ & 3.7 \\
\hline $\mathrm{NO}_{2}$ & 0.9 \\
\hline $\mathrm{NO}_{3}$ & 0.6 \\
\hline $\mathrm{OH}$ & 1 \\
\hline $\mathrm{Si}$ & 0.02 \\
\hline
\end{tabular}

12. CWP. In 1963, some coating waste from the PUREX Plant was called CWP. See waste type CW. 
13. CWR. REDOX process waste resulting from the dissolution of fuel element cladding. Both aluminum- and zircaloy-clad fuels were processed.

Approximate Composition of
Aluminum Cladding Waste
\begin{tabular}{|l|l|}
\hline Element/isotope & mol/L \\
\hline $\mathrm{Al}$ & 2.32 \\
\hline $\mathrm{Na}$ & 5.9 \\
\hline $\mathrm{NO}_{2}$ & 1.47 \\
\hline $\mathrm{NO}_{3}$ & 1.07 \\
\hline $\mathrm{OH}$ & 1 \\
\hline $\mathrm{Pu}$ & 0.000004 \\
\hline $\mathrm{U}$ & 0.0058 \\
\hline
\end{tabular}

Approximate Composition of

Zircaloy Cladding Waste

\begin{tabular}{|l|l|}
\hline Element/isotope & $\mathrm{mol} / \mathrm{L}$ \\
\hline $\mathrm{Al}$ & 0.21 \\
\hline $\mathrm{F}$ & 2.25 \\
\hline $\mathrm{Na}$ & 3.73 \\
\hline $\mathrm{NO}_{2}$ & 0.17 \\
\hline $\mathrm{NO}_{3}$ & 0.97 \\
\hline $\mathrm{OH}$ & 1.39 \\
\hline $\mathrm{P}$ & 0.000008 \\
\hline $\mathrm{U}$ & 0.018 \\
\hline $\mathrm{Zr}$ & 0.31 \\
\hline
\end{tabular}

14. Diatomaceous earth (DE). $\mathrm{SiO}_{2}$. 
15. DSSE. Noncomplexed waste that has been concentrated in evaporators until the solution is nearly saturated with sodium aluminate. Further evaporation will yield a slurry that is not suitable for storage in SSTs. This is a general term for noncomplexed HDRL (Hanford defense residual liquor), including partially neutralized waste.

Typical Composition

\begin{tabular}{|l|l|}
\hline Element/isotope & $\mathrm{mol} / \mathrm{L}$ \\
\hline $\mathrm{Al}$ & 1.74 \\
\hline $\mathrm{CO}_{3}$ & 0.21 \\
\hline $\mathrm{F}$ & 0.06 \\
\hline $\mathrm{Na}$ & 12.53 \\
\hline $\mathrm{NO}_{2}$ & 2.62 \\
\hline $\mathrm{NO}_{3}$ & 2.72 \\
\hline $\mathrm{OH}$ & 3.43 \\
\hline $\mathrm{PO}_{4}$ & 0.07 \\
\hline
\end{tabular}

16. Decontamination Waste (DW). This is a wash solution from equipment decontamination efforts at the T Plant. This waste was mainly a dilute $\mathrm{NaNO}_{2}$ solution, averaging $0.24 \mathrm{M} \mathrm{NaNO}$.

17. Evaporator Bottoms (EB). This is a slurry product from the evaporators. This slurry precipitated a solid salt cake that was stored in SSTs.

\section{Average Composition of \\ Sampled Salt Cake in 241-S Tank Farm}

\begin{tabular}{|l|c|}
\hline Element/isotope & $\begin{array}{c}\text { Weight } \\
\%\end{array}$ \\
\hline $\mathrm{H}_{2} \mathrm{O}$ & 12.8 \\
\hline $\mathrm{NaAlO}_{2}$ & 1.9 \\
\hline $\mathrm{Na}_{2} \mathrm{CO}_{3}$ & 6.4 \\
\hline $\mathrm{NaNO}_{2}$ & 1.8 \\
\hline $\mathrm{NaNO}_{3}$ & 73.8 \\
\hline $\mathrm{Na}_{3}\left(\mathrm{PO}_{4}\right)_{2}$ & 1.5 \\
\hline
\end{tabular}


18. Evaporator Feed (EE). This term designates various kinds of supernatant liquids whose composition depends on source location and whether they underwent prior concentration. In general, EF may be either dilute feed that has not yet been evaporated or concentrated feed that has been partially evaporated but requires additional evaporation to meet requirements for residual liquor.

Typical Composition of Dilute Feed

\begin{tabular}{|l|l|}
\hline Element/isotope & $\mathrm{mol} / \mathrm{L}$ \\
\hline $\mathrm{Al}$ & 0.4 \\
\hline $\mathrm{CO}_{3}$ & 0.2 \\
\hline $\mathrm{Na}$ & 4.5 \\
\hline $\mathrm{NO}_{2}$ & 0.6 \\
\hline $\mathrm{NO}_{3}$ & 2.3 \\
\hline $\mathrm{OH}$ & 0.7 \\
\hline $\mathrm{PO}_{4}$ & 0.03 \\
\hline
\end{tabular}

Typical Composition of Concentrated Feed

\begin{tabular}{|l|l|}
\hline Element/isotope & $\mathrm{mol} / \mathrm{L}$ \\
\hline $\mathrm{Al}$ & 0.9 \\
\hline $\mathrm{CO}_{3}$ & 0.23 \\
\hline $\mathrm{Na}$ & 8.26 \\
\hline $\mathrm{NO}_{2}$ & 1.6 \\
\hline $\mathrm{NO}_{3}$ & 3.6 \\
\hline $\mathrm{OH}$ & 1.7 \\
\hline $\mathrm{PO}_{4}$ & 0.05 \\
\hline
\end{tabular}

19. EVAP. This is a post-1976 designation for evaporator feed. For typical composition, see No. 18 Evaporator Feed (EF). With the exception of terminal liquors, which could not be further evaporated, and aging waste, which contained short-lived, high-heat fission products, any tank supernatant liquor could be designated evaporator feed.

20. Eission Products (EP) Waste. Waste produced at B Plant and Hot Semiworks during the 1960s in campaigns to isolate various fission products such as cerium and promethium. 
21. Hanford Defense Residual Liquor. This is a late 1970s designation for terminal liquors remaining after waste evaporation, these including complexed and noncomplexed waste, partially neutralized wastes, and DSSF. Further evaporation of these wastes would cause precipitation of solids unsuitable for storage in SSTs. Composition is the same as No. 44 Terminal Liquor, TL.

22. Hanford Laboratory Operations (HLO). Laboratory waste from 300 Area.

23. HS. Waste from Hot Semiworks Plant, which ran several strontium extraction campaigns from 1955 until 1961. There were 50,000 gallons of dilute wastes discharged to tank farms. For approximate chemical composition see SSW, Strontium Semiworks Waste.

24. Water (H2O). Filtered Hanford Site water (200 East Area) contains the following impurities in parts per million:

Filtered Hanford Site

200 East Water Impurities

\begin{tabular}{|l|c|}
\hline Element/isotope & ppm \\
\hline $\mathrm{Ca}$ & $20-40$ \\
\hline $\mathrm{Cl}$ & $1-5$ \\
\hline $\mathrm{CO}_{2}$ & $0-2$ \\
\hline $\mathrm{Mg}$ & $4-5.5$ \\
\hline $\mathrm{SO}_{4}$ & $14-30$ \\
\hline $\mathrm{SiO}_{4}$ & $3-7.5$ \\
\hline
\end{tabular}


25. IWW. Concentrated, neutralized high-level waste from the PUREX process. This waste type only entered the tank farms in one occurrence and is probably equivalent to waste type $P$. It should actually be written as $1 \mathrm{WW}$ and is bottom waste from the No. 1 acid concentrator.

Approximate Composition

\begin{tabular}{|l|l|}
\hline Element/isotope & $\mathrm{mol} / \mathrm{L}$ \\
\hline $\mathrm{Fe}$ & 0.05 \\
\hline $\mathrm{Na}$ & 5.37 \\
\hline $\mathrm{NO}_{3}$ & 5.82 \\
\hline $\mathrm{OH}$ & 5.37 \\
\hline $\mathrm{Pu}$ & 0.000007 \\
\hline $\mathrm{SO}_{4}$ & 0.1 \\
\hline $\mathrm{U}$ & 0.0126 \\
\hline
\end{tabular}

26. IX. Ion exchange waste from the cesium recovery process at the B Plant. Feed was PUREX supernate. This includes column waste, column wash waste, and cesium purification waste.

Approximate Composition
\begin{tabular}{|l|l|}
\hline Element/isotope & $\mathrm{mol} / \mathrm{L}$ \\
\hline $\mathrm{CO}_{3}$ & 0.65 \\
\hline $\mathrm{Na}$ & 3.9 \\
\hline $\mathrm{NO}_{2}$ & 1.9 \\
\hline $\mathrm{NO}_{3}$ & 0.49 \\
\hline $\mathrm{SO}_{4}$ & 0.085 \\
\hline
\end{tabular}

27. LW. Laboratory waste from 222-S Building. 
28. MW. Metal waste from the $\mathrm{BiPO}_{4}$ process. It was produced at the $\mathrm{B}$ and $\mathrm{T}$ Plants from the dissolution of uranium fuel elements.

Approximate Composition
\begin{tabular}{|l|c|}
\hline Element/isotope & mol/L \\
\hline $\mathrm{CO}_{3}$ & 1.14 \\
\hline $\mathrm{Na}$ & 3.53 \\
\hline $\mathrm{NO}_{3}$ & 0.59 \\
\hline $\mathrm{OH}$ & 1.16 \\
\hline $\mathrm{PO}_{4}$ & 0.23 \\
\hline $\mathrm{SO}_{4}$ & 0.24 \\
\hline $\mathrm{U}$ & 0.25 \\
\hline
\end{tabular}

29. N. Phosphate decontamination waste from N Reactor. After 1982 ionexchange regeneration waste containing sodium sulfate was produced. The following composition is for post-1980 N Reactor waste; N Reactor waste produced during the time when the SSTs were active is assumed to be similar.

\begin{tabular}{|c|c|}
\hline \multicolumn{2}{|c|}{$\begin{array}{c}\text { Approximate Composition of } \\
\text { Concentrated Phosphate } \\
\text { Waste }\end{array}$} \\
\hline Element/isotope & $\mathrm{mol} / \mathrm{L}$ \\
\hline $\mathrm{Na}$ & 1.11 \\
\hline $\mathrm{NO}_{2}$ & 0.014 \\
\hline $\mathrm{OH}$ & 0.01 \\
\hline $\mathrm{PO}_{4}$ & 0.36 \\
\hline
\end{tabular}


PNL-9814 Rev. 1

30. Noncomplexed Waste (NCPL). A general term for supernatant liquids and saltwell liquors not identified as containing organic complexants. This term came into use after 1976 and does not reflect origin or composition of the waste, only its suitability for further treatment.

Estimated Composition
\begin{tabular}{|l|l|}
\hline Element/isotope & mol/L \\
\hline $\mathrm{Al}$ & 1.5 \\
\hline $\mathrm{CO}_{3}$ & 0.2 \\
\hline $\mathrm{Na}$ & 10.6 \\
\hline $\mathrm{NO}_{2}$ & 2.2 \\
\hline $\mathrm{NO}_{3}$ & 3.3 \\
\hline $\mathrm{PO}_{4}$ & 0.08 \\
\hline
\end{tabular}

31. OWW. Organic solvent wash waste from the PUREX Plant, containing carbonate, permanganate, and nitrate.

Approximate Composition

\begin{tabular}{|l|l|}
\hline Element/isotope & $\mathrm{mol} / \mathrm{L}$ \\
\hline $\mathrm{CO}_{3}$ & 0.21 \\
\hline $\mathrm{K}$ & 0.01 \\
\hline $\mathrm{MnO}_{4}$ & 0.01 \\
\hline $\mathrm{MnO}_{2}$ & 0.01 \\
\hline $\mathrm{Na}$ & 0.27 \\
\hline $\mathrm{NO}_{3}$ & 0.06 \\
\hline $\mathrm{U}$ & 0.008 \\
\hline
\end{tabular}


PNL-9814 Rev. 1

32. P. High-activity neutralized acid waste generated by the PUREX process.

Approximate Composition
\begin{tabular}{|l|l|}
\hline Element/isotope & $\mathrm{mol} / \mathrm{L}$ \\
\hline $\mathrm{Al}$ & 0.15 \\
\hline $\mathrm{Fe}$ & 0.4 \\
\hline $\mathrm{Na}$ & 1.4 \\
\hline $\mathrm{NO}_{3}$ & 1.3 \\
\hline $\mathrm{PO}_{4}$ & 0.02 \\
\hline $\mathrm{SO}_{4}$ & 0.9 \\
\hline
\end{tabular}

33. PL. Low-level waste from the PUREX Plant.

Approximate Composition

\begin{tabular}{|l|l|}
\hline Element/isotope & $\mathrm{mol} / \mathrm{L}$ \\
\hline $\mathrm{Na}$ & 0.0013 \\
\hline $\mathrm{NO}_{3}$ & 0.0026 \\
\hline $\mathrm{Np}$ & $5.0 \mathrm{E}-7$ \\
\hline $\mathrm{Pu}$ & $3.2 \mathrm{E}-6$ \\
\hline $\mathrm{U}$ & 0.0013 \\
\hline
\end{tabular}

34. PNF. Waste used as feed for the partial neutralization campaigns conducted at the 242-S Evaporator during the late 1970s. Noncomplexed. For typical composition see No. 18, evaporator feed (EF). 
35. PUREX Sludge Supernatant (PSS) Liquid. PUREX sludge supernatant liquid was produced by leaching PUREX sludge. This sludge, in underground storage, resulted from the neutralization of PUREX high-level waste and the removal of supernatant liquids.

Approximate Composition

\begin{tabular}{|l|l|}
\hline Element/isotope & $\mathrm{mol} / \mathrm{L}$ \\
\hline $\mathrm{Al}$ & 0.04 \\
\hline $\mathrm{CO}_{3}$ & 0.24 \\
\hline $\mathrm{Cr}$ & 0.002 \\
\hline $\mathrm{Na}$ & 5.4 \\
\hline $\mathrm{NO}_{3}$ & 4.2 \\
\hline $\mathrm{NO}_{2}$ & 0.22 \\
\hline $\mathrm{SO}_{4}$ & 0.25 \\
\hline
\end{tabular}

36. B. High-level waste from the REDOX process.

Approximate Composition

\begin{tabular}{|l|l|}
\hline Element/isotope & $\mathrm{mol} / \mathrm{L}$ \\
\hline $\mathrm{Al}$ & 1.2 \\
\hline $\mathrm{Cr}$ & 0.177 \\
\hline $\mathrm{Fe}$ & 0.016 \\
\hline $\mathrm{Na}$ & 6.91 \\
\hline $\mathrm{NO}_{3}$ & 4.83 \\
\hline $\mathrm{OH}$ & 0.74 \\
\hline $\mathrm{PU}$ & $7.7 \mathrm{E}-7$ \\
\hline $\mathrm{SO}_{4}$ & 0.031 \\
\hline $\mathrm{U}$ & 0.0014 \\
\hline
\end{tabular}

37. RESD. A residual evaporator liquor. This is the same as HDRL, which in turn was formerly called TL. For composition see No. 44, Terminal Liquor (TL). 
38. REDOX Ion Exchange (RIX) Waste. Waste produced at B Plant after extraction of cesium from REDOX supernatant liquid by ion exchange. This includes column waste, column wash waste, and cesium purification waste.

Approximate Composition

\begin{tabular}{|l|l|}
\hline Element/isotope & $\mathrm{mol} / \mathrm{L}$ \\
\hline $\mathrm{Al}$ & 0.6 \\
\hline $\mathrm{Na}$ & 3.1 \\
\hline $\mathrm{NO}_{3}$ & 1.97 \\
\hline $\mathrm{NO}_{2}$ & 0.27 \\
\hline $\mathrm{OH}$ & 0.69 \\
\hline $\mathrm{SO}_{4}$ & 0.022 \\
\hline
\end{tabular}

39. REDOX Supernate (RSN). Supernatant liquor portion of waste generated by the REDOX process and found above sludge in underground storage tanks.

Approximate Composition
\begin{tabular}{|l|l|}
\hline Element/isotope & mol/L \\
\hline $\mathrm{Al}$ & 0.59 \\
\hline $\mathrm{Na}$ & 5.2 \\
\hline $\mathrm{NO}_{2}$ & 0.18 \\
\hline $\mathrm{NO}_{3}$ & 3.08 \\
\hline $\mathrm{OH}$ & 1.26 \\
\hline $\mathrm{SO}_{4}$ & 0.015 \\
\hline
\end{tabular}


40. SIX. Waste resulting from the removal of cesium from PUREX sludge supernatant liquid (see waste type PSS) by ion exchange at the B Plant. The given composition includes column waste, wash waste, and cesium purification waste.

Approximate Composition
\begin{tabular}{|l|l|}
\hline Element/isotope & $\mathrm{mol} / \mathrm{L}$ \\
\hline $\mathrm{Al}$ & 0.027 \\
\hline $\mathrm{CO}_{3}$ & 0.16 \\
\hline $\mathrm{Cr}$ & 0.0013 \\
\hline $\mathrm{Na}$ & 2.93 \\
\hline $\mathrm{NO}_{2}$ & 0.4 \\
\hline $\mathrm{NO}_{3}$ & 2.76 \\
\hline $\mathrm{SO}_{4}$ & 0.16 \\
\hline
\end{tabular}


41. Strontium Sludge (SRS). Sludge feed for the strontium extraction process at the B Plant. This waste type turned up during the mid-1970's and most likely originated largely from the PUREX process. Three compositions of PUREX sludges are given, two from sample analyses and one estimated from knowledge of essential material consumption and chemical behavior. The first waste composition is clearly labeled PUREX sludge but is not dated nor is a sampling method given. The third waste composition given here represents a homogenized core sample of the tank and may contain a variety of sludges. The one estimated composition contains less water than the actual compositions. The discrepancies between these three compositions reflect the difficulty of relying on a wide variety of sources to characterize highly variable waste types.

Composition of a Sampled

Sludge from Tank 241-C-106

\begin{tabular}{|l|l|}
\hline Element/isotope & \multicolumn{1}{c|}{$\mathrm{mol} / \mathrm{L}$} \\
\hline $\mathrm{Al}^{*}$ & 1.95 \\
\hline $\mathrm{Ba}$ & $<0.04$ \\
\hline $\mathrm{Ca}^{*}$ & 0.2 \\
\hline $\mathrm{Fe}^{*}$ & 1.78 \\
\hline $\mathrm{Mg}$ & 0.09 \\
\hline $\mathrm{Mn}$ & 0.55 \\
\hline $\mathrm{Na}$ & 2.2 \\
\hline $\mathrm{OH}$ & 5.74 \\
\hline $\mathrm{Pu}^{\mathrm{O}}$ & 0.00025 \\
\hline $\mathrm{Si}^{*}$ & 0.136 \\
\hline
\end{tabular}

* Assuming Al present as $\mathrm{NaAlO}_{2}, \mathrm{Fe}$ as $\mathrm{Fe}(\mathrm{OH})_{3}, \mathrm{Ca}$ as $\mathrm{Ca}(\mathrm{OH})_{2}$, and $\mathrm{Si}$ as $\mathrm{Na}_{2} \mathrm{SiO}_{3}$. 
PNL-9814 Rev. 1

Composition of a Composite of Sampled Solids from Tank 241-C-

106 Done in September 1976

\begin{tabular}{|l|l|}
\hline \multicolumn{1}{|c|}{ Element/isotope } & $\mathrm{mol} / \mathrm{L}$ \\
\hline $\mathrm{Al}$ & 2.11 \\
\hline $\mathrm{Ca}$ & 0.425 \\
\hline $\mathrm{Fe}$ & 1.33 \\
\hline $\mathrm{Mg}$ & 0.386 \\
\hline $\mathrm{Na}$ & 7.27 \\
\hline $\mathrm{P}$ & 0.13 \\
\hline $\mathrm{Si}$ & 3.61 \\
\hline $\mathrm{TOC}$ & $6.6 \mathrm{gm} / \mathrm{L}$ \\
\hline
\end{tabular}

PUREX Sludge Composition

\begin{tabular}{|l|c|}
\hline \multicolumn{1}{|c|}{ Element/isotope } & $\mathrm{mol} / \mathrm{L}$ \\
\hline $\mathrm{Al}$ & 3.87 \\
\hline $\mathrm{Fe}$ & 2.75 \\
\hline $\mathrm{Mn}$ & 0.8 \\
\hline $\mathrm{Na}$ & 12.96 \\
\hline $\mathrm{OH}$ & 8.25 \\
\hline $\mathrm{PO}{ }_{4}$ & 0.27 \\
\hline $\mathrm{Si}$ & 4.14 \\
\hline $\mathrm{Zr}$ & 1.1 \\
\hline
\end{tabular}

* This is a theoretical PUREX sludge composition based on known consumption of essential materials and known solubility behavior of ionic species. 
42. Strontium Semiworks Waste (SSW). Waste produced from the strontium extraction process at the strontium semiworks after 1961. Feed was typically PUREX high-level acid waste.

Approximate Composition
\begin{tabular}{|l|l|}
\hline Element/isotope & mol/L \\
\hline $\mathrm{Ba}$ & 0.0002 \\
\hline $\mathrm{Ca}$ & 0.0049 \\
\hline $\mathrm{Ce}$ & 0.0017 \\
\hline $\mathrm{C}_{2} \mathrm{H}_{3} \mathrm{O}_{2}$ (acetate) & 1.34 \\
\hline $\mathrm{Fe}$ & 0.03 \\
\hline $\mathrm{K}$ & 0.078 \\
\hline $\mathrm{Na}$ & 4.9 \\
\hline $\mathrm{NO}{ }_{3}$ & 2.1 \\
\hline $\mathrm{OH}$ & 1.32 \\
\hline $\mathrm{Pb}$ & 0.034 \\
\hline $\mathrm{RE}$ & 0.0069 \\
\hline $\mathrm{Sr}$ & 0.0005 \\
\hline
\end{tabular}

43. TBP. Waste from the TBP uranium-extraction process at U Plant, composed of concentrated, neutralized aqueous effluents from the primary extraction column and from the solvent wash.

Approximate Composition

\begin{tabular}{|l|l|}
\hline Element/isotope & $\mathrm{mol} / \mathrm{L}$ \\
\hline $\mathrm{Cl}$ & 0.0025 \\
\hline $\mathrm{Fe}$ & 0.03 \\
\hline $\mathrm{Na}$ & 8.87 \\
\hline $\mathrm{NO}_{3}$ & 7.35 \\
\hline $\mathrm{OH}$ & 0.09 \\
\hline $\mathrm{PO}_{4}$ & 0.3 \\
\hline $\mathrm{Pu}$ & $6.7 \mathrm{E}-7$ \\
\hline $\mathrm{SO}_{4}$ & 0.31 \\
\hline $\mathrm{U}$ & 0.0061 \\
\hline
\end{tabular}


44. Terminal Liquor (TL). Terminal liquor produced by evaporators as a concentrated supernatant liquid decanted from the evaporator bottoms. Terminal liquor is defined as evaporator liquor that may not be evaporated further without producing solids that are unsatisfactory for storage in SSTs. These undesirable solids may be either deliquescent caustic salts, fine and poorly draining aluminate solids, or gelled organic complexants.

Typical Composition

\begin{tabular}{|l|l|}
\hline Element/isotope & $\mathrm{mol} / \mathrm{L}$ \\
\hline $\mathrm{Al}$ & 2.3 \\
\hline $\mathrm{CO}_{3}$ & 0.2 \\
\hline $\mathrm{Na}$ & 12.6 \\
\hline $\mathrm{NO}_{2}$ & 3.0 \\
\hline $\mathrm{NO}_{3}$ & 2.5 \\
\hline $\mathrm{OH}$ & 4.4 \\
\hline $\mathrm{PO}_{4}$ & 0.001 \\
\hline
\end{tabular}


PNL-9814 Rev. 1

45. 1C. First-cycle decontamination waste from the $\mathrm{BiPO}_{4}$ process at $\mathrm{B}$ and T Plants. This waste type consists of byproducts coprecipitated from a plutonium-containing solution. Coating waste from the removal of aluminum fuel element cladding was added and composed about $24 \%$ of this waste stream.

Approximate Composition

\begin{tabular}{|l|l|}
\hline Element/isotope & \multicolumn{1}{|c|}{$\mathrm{mol} / \mathrm{L}$} \\
\hline $\mathrm{Al}$ & 0.38 \\
\hline $\mathrm{Bi}$ & 0.012 \\
\hline $\mathrm{Ce}$ & 0.00022 \\
\hline $\mathrm{Cr}$ & 0.0016 \\
\hline $\mathrm{F}$ & 0.19 \\
\hline $\mathrm{Fe}$ & 0.025 \\
\hline $\mathrm{Na}$ & 3.34 \\
\hline $\mathrm{NO}{ }_{2}$ & 0.28 \\
\hline $\mathrm{NO}_{3}$ & 1.54 \\
\hline $\mathrm{OH}$ & 0.28 \\
\hline $\mathrm{PO}_{4}$ & 0.28 \\
\hline $\mathrm{PU}$ & 0.00002 \\
\hline $\mathrm{Si}$ & 0.034 \\
\hline $\mathrm{SO}_{4}$ & 0.052 \\
\hline
\end{tabular}


46. 2C. Waste from the second decontamination cycle of the $\mathrm{BiPO}_{4}$ process at $\mathrm{B}$ and $T$ Plants and consisting of effluent remaining after precipitation of plutonium product.

Approximate Composition
\begin{tabular}{|l|l|}
\hline Element/isotope & $\mathrm{mol} / \mathrm{L}$ \\
\hline $\mathrm{Bi}$ & 0.0092 \\
\hline $\mathrm{Cr}$ & 0.0025 \\
\hline $\mathrm{F}$ & 0.22 \\
\hline $\mathrm{Fe}$ & 0.023 \\
\hline $\mathrm{Na}$ & 2.04 \\
\hline $\mathrm{NO}_{3}$ & 1.27 \\
\hline $\mathrm{PO}_{4}$ & 0.34 \\
\hline $\mathrm{Si}$ & 0.037 \\
\hline $\mathrm{SO}_{4}$ & 0.062 \\
\hline
\end{tabular}

47. 224. Waste from the final decontamination and concentration stage of the $\mathrm{BiPO}_{4}$ process. In this stage, first the byproducts and finally the plutonium product are precipitated with lanthanum fluoride. This waste was largely sent into the ground through reverse flow wells and underground sumps.

Approximate Composition
\begin{tabular}{|l|l|}
\hline Element/isotope & $\mathrm{mol} / \mathrm{L}$ \\
\hline $\mathrm{Bi}$ & 0.0062 \\
\hline $\mathrm{Cr}$ & 0.0009 \\
\hline $\mathrm{F}$ & 0.31 \\
\hline $\mathrm{H}_{2} \mathrm{C}_{2} \mathrm{O}_{4}$ (oxalate) & 0.028 \\
\hline $\mathrm{K}$ & 0.26 \\
\hline $\mathrm{La}$ & 0.0014 \\
\hline $\mathrm{Mn}$ & 0.0046 \\
\hline $\mathrm{Na}$ & 1.75 \\
\hline $\mathrm{NO}_{3}$ & 1.06 \\
\hline $\mathrm{OH}$ & 0.59 \\
\hline $\mathrm{PO}_{4}$ & 0.049 \\
\hline
\end{tabular}


PNL-9814 Rev. 1

48. 5-6. Waste from Tank 5-6 at B Plant. This is a very hot waste that collected in the bottom of Section 5 at B Plant due to boil-over during dissolving and neutralization during the $\mathrm{BiPO}_{4}$ process.

49. Z. Waste discharged from the Plutonium Finishing Plant during the late 1970s. Waste from the Plutonium Reclamation Facility and the Remote Mechanical C Line was sent to evaporators and put in SSTs. At times, slag and crucibles from processing of plutonium metal were used as feed material for plutonium reclamation, changing the waste composition.

Approximate Composition Without

Slag and Crucible Processing

\begin{tabular}{|l|l|}
\hline \multicolumn{1}{|c|}{ Element/isotope } & $\mathrm{mol} / \mathrm{L}$ \\
\hline $\mathrm{Al}$ & 0.5 \\
\hline $\mathrm{Ba}$ & 0.000003 \\
\hline $\mathrm{Ca}$ & 0.00071 \\
\hline $\mathrm{Cr}$ & 0.0014 \\
\hline $\mathrm{Fe}$ & 0.0007 \\
\hline $\mathrm{K}$ & 0.0007 \\
\hline $\mathrm{Mg}$ & 0.000021 \\
\hline $\mathrm{Mn}$ & 0.0007 \\
\hline $\mathrm{Na}$ & 4 \\
\hline $\mathrm{Ni}$ & 0.00057 \\
\hline $\mathrm{Pb}$ & 0.00036 \\
\hline $\mathrm{Sr}$ & 0.000021 \\
\hline $\mathrm{OH}$ & 0.0001 \\
\hline $\mathrm{Cl}$ & 0.041 \\
\hline $\mathrm{F}$ & 0.047 \\
\hline $\mathrm{NO}_{3}$ & 3.5 \\
\hline $\mathrm{NO}_{2}$ & 0.014 \\
\hline $\mathrm{PO}$ & 0.00014 \\
\hline $\mathrm{SO}_{4}$ & 0.0014 \\
\hline $\mathrm{TRU}$ & 0.00006 \\
\hline $\mathrm{U}$ & 0.00001 \\
\hline $\mathrm{TOC}$ & $3 \mathrm{~g} / \mathrm{L}$ \\
\hline & \\
\hline
\end{tabular}


PNL-9814 Rev. 1

Approximate Composition

with Slag and Crucible

Processing (where different

from above)

\begin{tabular}{|l|l|}
\hline Element/isotope & $\mathrm{mol} / \mathrm{L}$ \\
\hline $\mathrm{Ca}$ & 0.014 \\
\hline $\mathrm{Fe}$ & 0.0071 \\
\hline $\mathrm{F}$ & 0.018 \\
\hline $\mathrm{I}$ & 0.00016 \\
\hline $\mathrm{NO}_{2}$ & 0.0065 \\
\hline
\end{tabular}



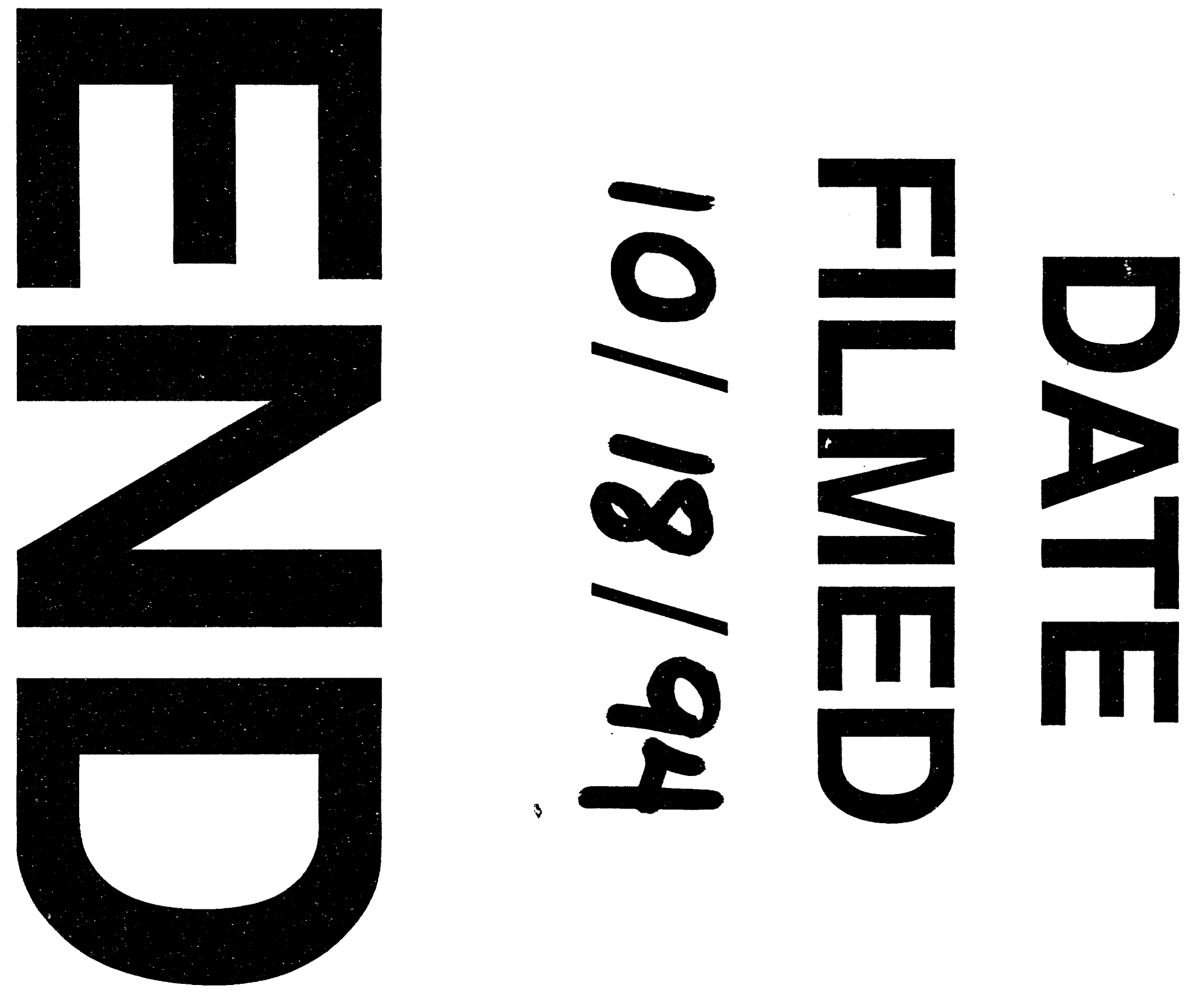
